\title{
Global upper-tropospheric formaldehyde: seasonal cycles observed by the ACE-FTS satellite instrument
}

\author{
G. Dufour ${ }^{1}$, S. Szopa ${ }^{2}$, M. P. Barkley ${ }^{3}$, C. D. Boone ${ }^{4}$, A. Perrin ${ }^{1}$, P. I. Palmer ${ }^{3}$, and P. F. Bernath ${ }^{4,5}$ \\ ${ }^{1}$ Laboratoire Inter-universitaire des Systèmes Atmosphériques (LISA), UMR7583, Universités Paris 12 et Paris 7, CNRS, \\ Créteil, France \\ ${ }^{2}$ Laboratoire des Sciences du Climat et de l'Environnement (LSCE/IPSL), CNRS-CEA-UVSQ Gif-sur-Yvette, France \\ ${ }^{3}$ School of GeoSciences, University of Edinburgh, UK \\ ${ }^{4}$ Department of Chemistry, University of Waterloo, Ontario, N2L 3G1, Canada \\ ${ }^{5}$ Department of Chemistry, University of York, Heslington, York, YO10 5DD, UK
}

Received: 17 November 2008 - Published in Atmos. Chem. Phys. Discuss.: 13 January 2009

Revised: 14 April 2009 - Accepted: 5 June 2009 - Published: 16 June 2009

\begin{abstract}
Seasonally-resolved upper tropospheric profiles of formaldehyde (HCHO) observed by the ACE Fourier transform spectrometer (ACE-FTS) on a near-global scale are presented for the time period from March 2004 to November 2006. Large upper tropospheric $\mathrm{HCHO}$ mixing ratios ( $>150$ pptv) are observed during the growing season of the terrestrial biosphere in the Northern Hemisphere and during the biomass burning season in the Southern Hemisphere. The total errors estimated for the retrieved mixing ratios range from 30 to $40 \%$ in the upper troposphere and increase in the lower stratosphere. The sampled HCHO concentrations are in satisfactory agreement with previous aircraft and satellite observations with a negative bias $(<25 \%)$ within observation errors. An overview of the seasonal cycle of the upper tropospheric $\mathrm{HCHO}$ is given for different latitudes, with a particular focus on mid-to-high latitudes that are well sampled by the observations. A maximum is observed during summer, i.e. during the growing season, in the northern mid- and high latitudes. The influence of biomass burning is visible in $\mathrm{HCHO}$ upper tropospheric concentrations during the September-to-October period in the southern tropics and subtropics. Comparisons with two state-of-the-art models (GEOS-Chem and LMDz-INCA) show that the models capture well the seasonal variations observed in the Northern Hemisphere (correlation $>0.9$ ). Both models underestimate the summer maximum over Europe and Russia and differences in the emissions used for North America result in a
\end{abstract}

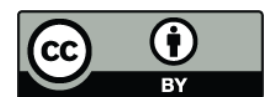

Correspondence to: G. Dufour (dufour@lisa.univ-paris12.fr) good reproduction of the summer maximum by GEOS-Chem but in an underestimate by LMDz-INCA. Globally, GEOSChem reproduces well the observations on average over one year but has some difficulties in reproducing the spatial variability of the observations. LMDz-INCA shows significant bias in the Southern Hemisphere, perhaps related to an underestimation of methane, but better reproduces the temporal and spatial variations. The differences between the models underline the large uncertainties that remain in the emissions of $\mathrm{HCHO}$ precursors.

\section{Introduction}

Formaldehyde (HCHO) is an important intermediate compound in the degradation of the volatile organic compounds (VOCs), including methane $\left(\mathrm{CH}_{4}\right)$, in the troposphere. Oxidation of VOCs by $\mathrm{OH}$ leads to the formation of organic peroxy radicals that produce $\mathrm{HCHO}$ either directly or through the degradation of other species (Atkinson, 1994, 2000; Fig. 1 in Frost et al., 2002). The relative importance of these reactions is mainly controlled by the concentration of $\mathrm{NO}$, which therefore plays a decisive role in $\mathrm{HCHO}$ production. Under low NO conditions, intermediate compounds like methyl hydrogen peroxide $\left(\mathrm{CH}_{3} \mathrm{OOH}\right)$ may be removed by deposition before reaction with $\mathrm{OH}$ takes place. Formaldehyde plays an important role in $\mathrm{HO}_{\mathrm{x}}$ chemistry and in ozone production as a source of $\mathrm{HO}_{2}$ (Fig. 1 in Frost et al., 2002) especially in the upper troposphere where water vapor, the main source of odd oxygen, has a low concentration. In addition to being a significant source of $\mathrm{HO}_{\mathrm{x}}$ in the

Published by Copernicus Publications on behalf of the European Geosciences Union. 

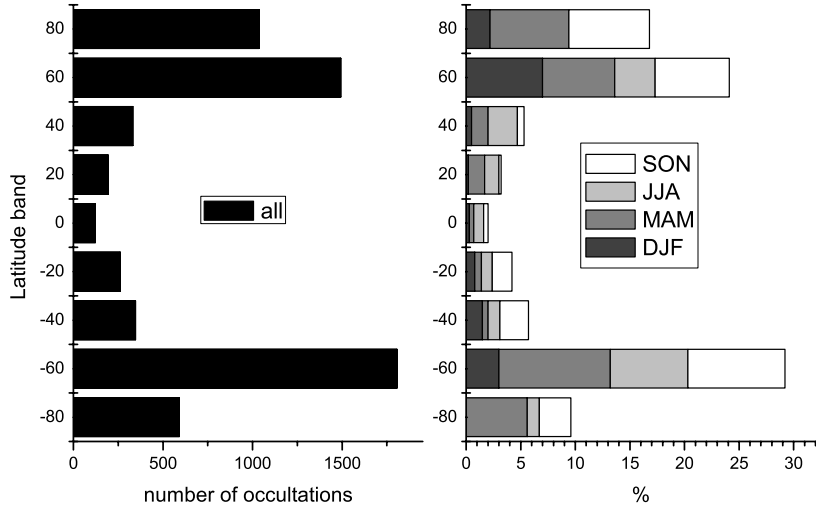

Fig. 1. (left) Total number of occultations per $20^{\circ}$ latitude band; (right) Portion (\%) of occultations (selected for $\mathrm{HCHO}$ ) for each latitude and each season.

upper troposphere, $\mathrm{HCHO}$ is also more sensitive than $\mathrm{HO}_{\mathrm{x}}$ to changes in precursor species (Crawford et al., 1999) and can be used as an indicator of additional $\mathrm{HO}_{\mathrm{x}}$ sources. Moreover, HCHO is often used as a tracer of recent photochemical activity (i.e. as a pollution tracer) due to its relatively short lifetime (several hours). As it is an intermediate product from a wide range of hydrocarbons, it can also be used to test our mechanistic understanding of tropospheric oxidation reactions.

Methane is known to be the main source of $\mathrm{HCHO}$ throughout the troposphere. However, close to large source regions, the oxidation of non-methane hydrocarbons can make a significant contribution to formaldehyde concentrations especially in the continental boundary layer (Pfister et al., 2008; Stavrakou et al., 2009; Dufour et al., 2009). $\mathrm{HCHO}$ production from anthropogenic VOCs is most significant in urban areas but production from biogenic sources dominates elsewhere especially during the growing season of vegetation with the largest contribution coming from isoprene (e.g. Palmer et al., 2003, 2006; Millet et al., 2008). In addition, formaldehyde is also directly emitted into the atmosphere by biomass burning (Lee et al., 1997), incomplete combustion (de Serves, 1994), industrial processes, and by vegetation (e.g. Kesselmeier and Staudt, 1999; Lathière et al., 2006). In the upper troposphere, the altitude range of interest in this paper, Fried et al. (2008b) have determined the contribution of different source species to the total $\mathrm{HCHO}$ production. More than $50 \%$ of $\mathrm{HCHO}$ is produced by methane oxidation. This portion decreases to about $40 \%$ in air masses with enhanced concentrations of tracer species and these fractions are in a good agreement with those derived by Stickler et al. (2006) in another region. Both studies reveal the role of convection and lightning (producing additional NO) as an additional source of formaldehyde in the upper troposphere. The non-methane part of HCHO production is mainly from biogenic primary species such as methanol

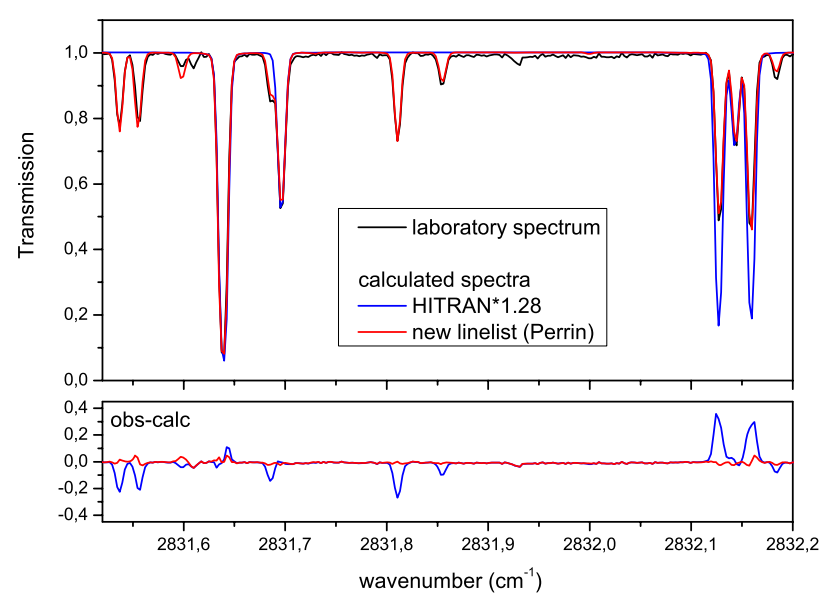

Fig. 2. Comparison between an observed laboratory spectrum and a spectrum calculated with the spectroscopic parameters from $\mathrm{HI}-$ TRAN (with the intensities modified by a factor 1.28) in blue and from a new linelist in red (Perrin et al., 2009). The corresponding residuals (observed-calculated) are displayed in the lower panel.

or from secondary species produced from the oxidation of short-lived primary biogenic species like isoprene, and then transported to the upper troposphere. The sinks of $\mathrm{HCHO}$ are mainly photolysis and reaction with $\mathrm{OH}$, and ultimately lead to the formation of carbon monoxide and $\mathrm{HO}_{2}$.

In the continental boundary layer, $\mathrm{HCHO}$ concentrations of the order of a few parts per billion by volume (ppbv) are reported and can reach values greater than $10 \mathrm{ppbv}$ in large cities (Dasgupta et al., 2005) and tropical regions (Kesselmeier et al., 2002). The HCHO concentration falls below $0.5 \mathrm{ppbv}$ far from the sources in the oceanic background atmosphere for example (e.g., Heikes et al., 2001; Fried et al; 2002, 2003a; Frost et al., 2002). Its abundance decreases with altitude and can reach values as low as a few tens pptv (part per trillion by volume) in the upper troposphere (e.g., Fried et al., 2003a).

Formaldehyde has been measured and studied for more than two decades in the upper troposphere through various aircraft campaigns (e.g. Arlander et al., 1995; Lee et al., 1997; Heikes et al., 2001; Fried et al., 2002; Kormann et al., 2003; Singh et al., 2000, 2004, 2006). These campaigns took place at different latitudes and in different seasons and give a general picture of the $\mathrm{HCHO}$ distribution, but the sampling remains very sparse and sporadic.

The Atmospheric Chemistry Experiment infrared Fourier transform spectrometer (ACE-FTS) onboard the SCISAT satellite (Bernath et al., 2005) provides a new dataset that covers a large time period ( 3 years are analyzed here) and large parts of the globe compared to previous measurements. Up to now, satellite measurements of $\mathrm{HCHO}$ were performed either by UV-visible nadir sounders (e.g., GOME, SCIAMACHY, OMI) that provide tropospheric columns mostly 
Table 1. Characteristics of the microwindows used for HCHO retrieval.

\begin{tabular}{|c|c|c|c|c|}
\hline $\begin{array}{l}\text { Microwin } \\
\text { center }\end{array}$ & $\begin{array}{l}\text { dow }\left(\mathrm{cm}^{-1}\right) \\
\text { width }\end{array}$ & Altitude range & Fitted interferers & Fixed interferers \\
\hline 2739.85 & 0.60 & \multirow{6}{*}{$5-25 \mathrm{~km}$} & \multirow{6}{*}{$\begin{array}{l}\mathrm{OC}^{18} \mathrm{O}, \mathrm{O}_{3}, \mathrm{~N}_{2} \mathrm{O}, \mathrm{N}^{15} \mathrm{NO}, \mathrm{CH}_{4}, \\
{ }^{13} \mathrm{CH}_{4}, \mathrm{HDO}, \mathrm{HD}^{18} \mathrm{O}\end{array}$} & \multirow{6}{*}{ OCS, $\mathrm{C}_{2} \mathrm{H}_{2}, \mathrm{H}_{2} \mathrm{O}$} \\
\hline 2765.65 & 0.45 & & & \\
\hline 2778.40 & 1.00 & & & \\
\hline 2781.20 & 0.80 & & & \\
\hline 2812.25 & 0.70 & & & \\
\hline 2826.67 & 0.80 & & & \\
\hline
\end{tabular}

sensitive to the lower troposphere (e.g., Chance et al., 2000; Palmer et al., 2001; Wittrock et al., 2006; Millet et al., 2008) or by limb viewers (e.g., MIPAS, SMR) that provide profiles but mainly limited to the stratosphere (Steck et al., 2008; Ricaud et al., 2007). Measurements of formaldehyde profiles in the upper troposphere from the ACE-FTS therefore represent a unique data set for investigating the seasonal variation in this altitude region, with a more specific focus on the mid and high latitudes (better covered by the instrument).

After characterization of the ACE-FTS formaldehyde retrieval (Sect. 2), the validity of the volume mixing ratios observed is evaluated using aircraft and other satellite measurements (Sect. 3). Almost three years of ACE-FTS measurements have been analyzed and are presented in Sect. 4. The observations are finally compared with two state-of-the-art CTMs (GEOS-Chem and LMDz-INCA) in Sect. 5.

\section{ACE-FTS measurements}

The aim of the Atmospheric Chemistry Experiment (ACE) satellite mission (Bernath et al., 2005), launched in August 2003 , is to investigate atmospheric composition primarily in the upper troposphere and in the stratosphere. Solar occultation measurements are made with coverage between approximately $85^{\circ} \mathrm{S}$ and $85^{\circ} \mathrm{N}$, with a majority of observations in the $50^{\circ}-70^{\circ}$ latitude band of both hemispheres (Fig. 1). It is worth noting that the observations are not equally distributed in space and time leading to an inhomogeneous global coverage (e.g., Bernath, 2006; Fu et al., 2007). The latitude coverage of the ACE-FTS for one year is given in Fig. 1 of Bernath et al. (2006). However, the orbital coverage yields a near global picture of the upper-tropospheric distributions of molecules rarely measured (e.g. Dufour et al., 2007; Barkley et al., 2008a). The primary instrument on board the satellite is the ACE-FTS, a high resolution $\left(0.02 \mathrm{~cm}^{-1}\right)$ Fourier transform spectrometer operating in the 750 to $4400 \mathrm{~cm}^{-1}$ range. Vertical profiles of temperature, pressure and various atmospheric constituents are retrieved from ACE-FTS spectra using a global fit approach coupled with a LevenbergMarquardt non-linear least squares method (Boone et al., 2005). The altitude resolution of the retrieved profiles is de- fined mainly by the field of view of the ACE-FTS instrument, and is about $3-4 \mathrm{~km}$. The HCHO vertical profiles discussed here are from a research version of the algorithm close to the future version 3.0. The ability to detect formaldehyde using the ACE-FTS has been first demonstrated by Coheur et al. (2007) in the case of enhanced concentrations in a biomass burning plume. Since then, the set of microwindows used for the retrieval has been refined.

\subsection{Selected microwindows}

Selected formaldehyde lines in the $3.6 \mu \mathrm{m}$ region are used for the retrieval. In this spectral region lie the strongest absorption bands $\left(v_{1}\right.$ and $\left.\nu_{5}\right)$ as well as several weaker overtone and combination bands (Perrin et al., 2006). Formaldehyde linelists currently available in databases like HITRAN (Rothmann et al., 2005) and GEISA (Jacquinet-Husson et al., 2008) fail to reproduce the observed laboratory spectra. Perrin et al. (2009) have pointed out several problems with these databases: (1) the line intensities quoted in HITRAN and GEISA are $28 \%$ too small on average, (2) significant lines are missing, (3) inconsistencies in blended or degenerate doublet lines in HITRAN sometimes lead to an intensity overestimate by a factor of 2 or 3 . Figure 2 illustrates the different problems that can be encountered using the current linelists. In order to avoid erroneous retrievals, a new HCHO linelist in the $3.6 \mu \mathrm{m}$ region was generated, which includes the line positions and line intensities generated in Perrin et al. (2006) and (2009), respectively. Also for the description of the HCHO line shapes, this linelist comprises the air broadening parameters given for all lines in the HITRAN linelist, namely $\gamma_{\mathrm{air}}=0.1080 \mathrm{~cm}^{-1} \mathrm{~atm}^{-1}$ for the air broadening halfwidths and $n=0.5$ for its temperature dependence.

The microwindows selected on the basis of this linelist are given in Table 1 as well as the interfering molecules in each window. The interferers are separated depending on whether they are simultaneously fitted with formaldehyde or if their mixing ratios are fixed during the retrieval. Three additional windows are used to better constrain HDO and $\mathrm{N}_{2} \mathrm{O}$. The retrieval is performed between 5 and $25 \mathrm{~km}$. The HCHO contribution to the atmospheric spectrum in the 

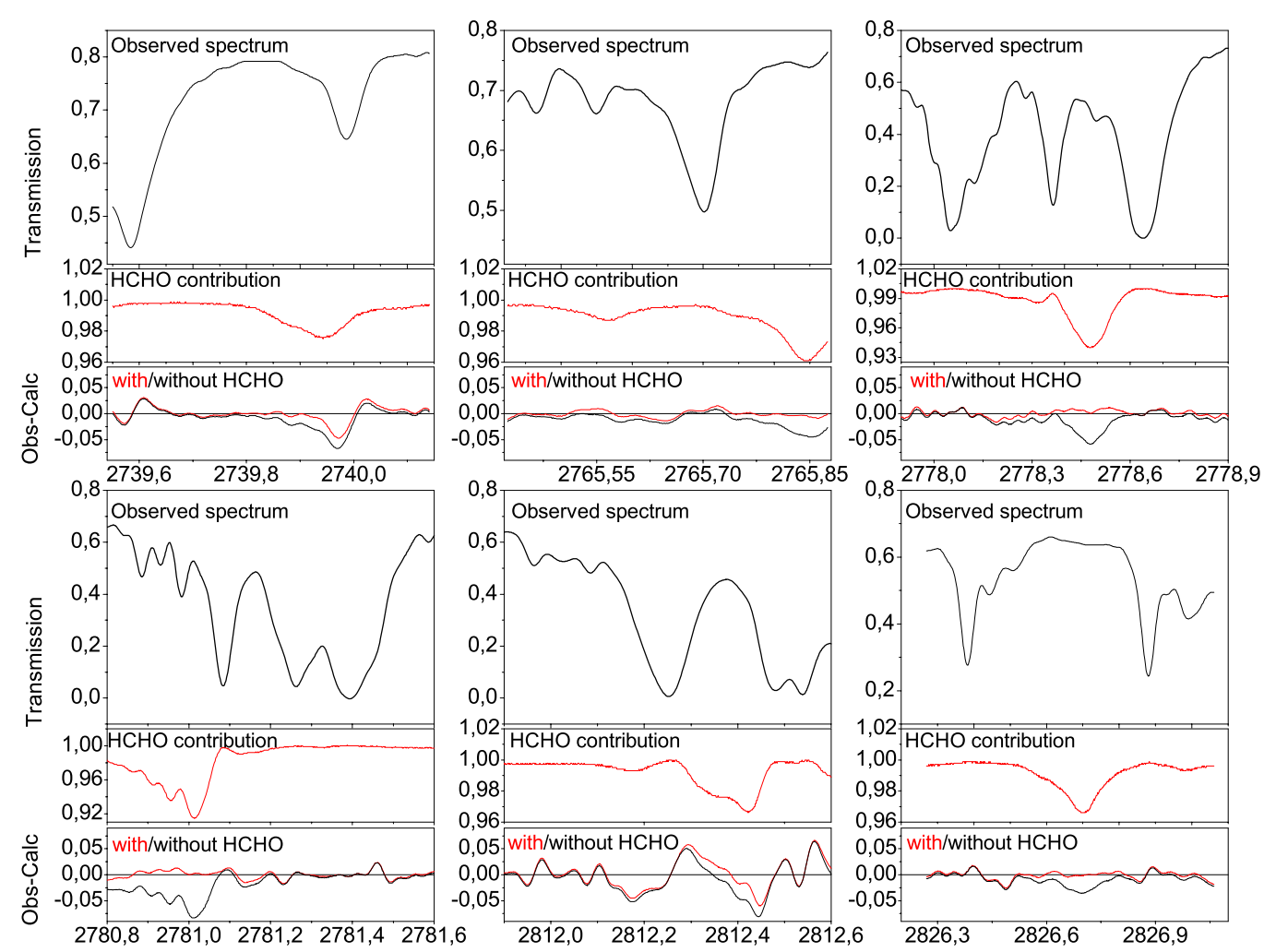

Fig. 3. Example of one spectrum observed by the ACE-FTS at $8 \mathrm{~km}$ in each microwindow selected for the retrieval of HCHO (top panels). The middle panels display the formaldehyde contribution to the atmospheric spectrum and the bottom panels display the residuals (observedcalculated) with the formaldehyde contribution included (red) or not (black) in the calculation.
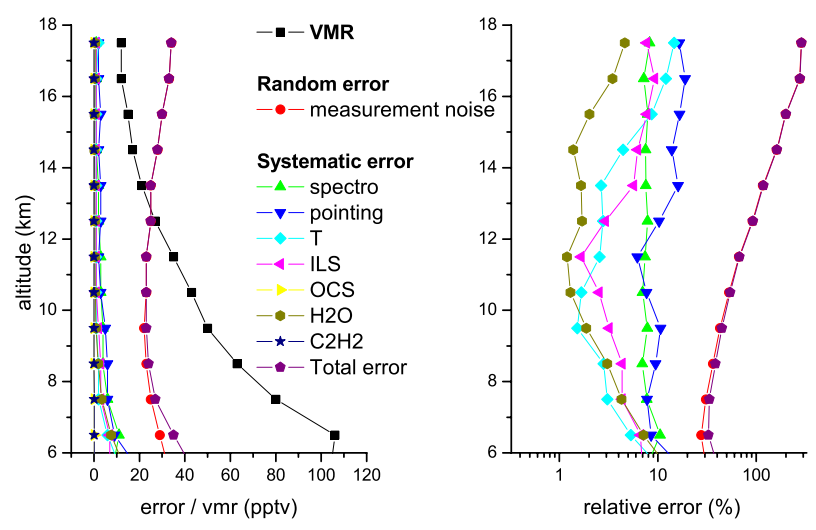

Fig. 4. Mean vmr profile of HCHO (black) for the 25 occultations selected for the estimation of the error budget. Each contribution of the error budget is given in absolute values on the left and in relative values on the right. selected microwindows is shown for an altitude of $8 \mathrm{~km}$ in Fig. 3. The residuals obtained using the observed spectra and the synthetic spectra calculated without including formaldehyde show features similar in shape and position to the calculated $\mathrm{HCHO}$ atmospheric contribution. It is worth noting that the $\mathrm{HCHO}$ contribution is weak and that additional features due to interferers remain.

\subsection{Error determination}

The error on the ACE-FTS observations is characterized by a random (or statistical) part and a systematic part. The statistical part, corresponding to the fitting error, is often named "measurement noise" (Eq. 2 in Dufour et al., 2006) and is represented in red in Fig. 4. The systematic part of the error is estimated by perturbing each parameter by $1 \sigma$ of its assumed uncertainty during the retrieval process as described by Dufour et al. (2006). Error sources accounting for uncertainties in temperature $(T)(2 \mathrm{~K})$, tangent altitude pointing $(150 \mathrm{~m})$, HCHO spectroscopic data $(8 \%$, Perrin et al., 2009), instrumental line shape (ILS, $5 \%$ of the field of view), and mixing ratios of the main interfering species (fixed during the retrieval, $20 \%$ for OCS and $\mathrm{C}_{2} \mathrm{H}_{2}$ and $10 \%$ for $\mathrm{H}_{2} \mathrm{O}$ ) are considered. The effects of uncertainties in the baseline of the 
spectra, spectral shifts and the simultaneously fitted interferers are not included in this sensitivity study because these parameters are fitted simultaneously with $\mathrm{HCHO}$. Due to computational cost, we applied our error estimation method to a limited number of occultations (about 25), selected to cover the range of measured $\mathrm{HCHO}$ profiles for different seasons. Figure 4 displays the mean error budget as well as the mean volume mixing ratio profile for these representative occultations. The total error indicated in Fig. 4 is an effective total error as the errors given for each uncertain parameter are the mean of the individual errors of each occultation. Considering the mean errors and the effective total error gives a better representation of the sensitivity of the $\mathrm{HCHO}$ retrieval to uncertainties rather than considering just a single occultation. However, we also checked individual occultations to ensure that the average sensitivities were representative. Except for the measurement noise that largely dominates the error, the $\mathrm{HCHO}$ retrieval is mainly sensitive to uncertainties in the tangent height determination and in the $\mathrm{HCHO}$ spectroscopy. The total error (Fig. 4) ranges between 30 and $40 \%$ up to $9 \mathrm{~km}$, increases with altitude and exceed $100 \%$ above $13 \mathrm{~km}$, as expected given the remaining residuals of the main interferers (Fig. 3). For a subset of occultations with upper tropospheric vmrs smaller than $100 \mathrm{pptv}$, the total error is slightly larger, between 40 and $50 \%$ up to $9 \mathrm{~km}$ and exceeds $100 \%$ above $11 \mathrm{~km}$. Note that averaged mixing ratios (vmrs) are often considered in the next sections. In this case, the statistical component of the error is reduced (divided approximately by the square root of the number of averaged vmrs). The resulting total error (statistical+systematic) is then dominated by the systematic error that remains smaller than $15 \%$ in the considered altitude range.

\section{Comparison with independent measurements}

\subsection{Aircraft measurements}

Various aircraft campaigns have been carried out in the two last decades, providing formaldehyde measurements in the free and upper troposphere for different regions and different seasons. Some examples of these campaigns are TROPOZ II in winter 1991 (Arlander et al., 1995), TRACE-A in fall 1992 (e.g., Lee et al., 1997), PEM - West in spring 1994 (Heikes et al., 2001), NARE97 (Fried et al., 2002) and SONEX (Singh et al., 2000) in fall 1997, TOPSE in spring 2000 (Fried et al., 2003b), TRACE-P in spring 2001 (Singh et al., 2004), MINOS in summer 2001 (Kormann et al., 2003), UTOPIHAN in summer 2003 (Stickler et al., 2006), and INTEXNA in summer 2004 (Fried et al., 2008a, b). The difficulties in using these aircraft measurements to compare with ACE-FTS observations reside in the differences in the sampling of aircraft and satellite observations. We selected campaigns for which aircraft data are available in the 6-12 km range in the literature. Unfortunately, only campaigns in

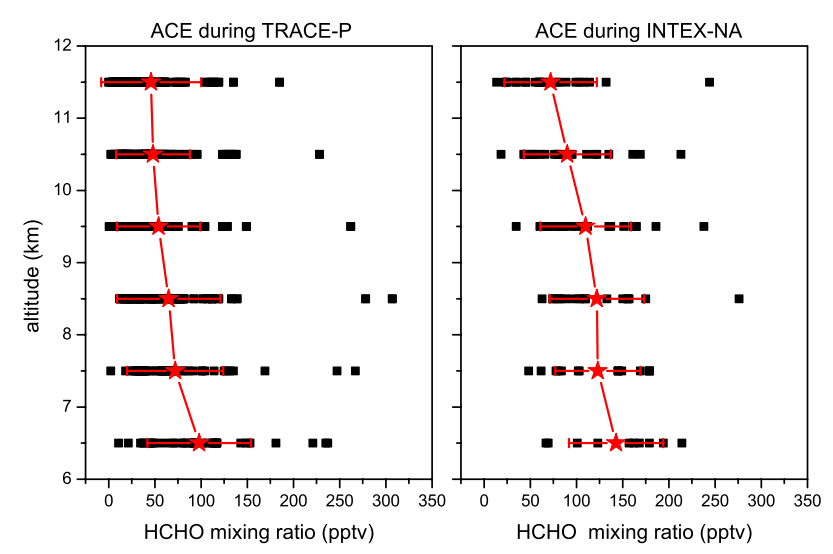

Fig. 5. HCHO mixing ratios measured by the ACE-FTS near the TRACE-P and INTEX-NA flight tracks during the time period of the aircraft campaigns over 3 years (2004 to 2006). The mean mixing ratio for ACE-FTS is reported (red stars) for each altitude with its $1 \sigma$ standard deviation.

the Northern Hemisphere match this criterion with enough ACE-FTS data to be useful. We compared ACE-FTS observations with upper tropospheric observations made during two campaigns: TRACE-P (Singh et al., 2004; Fried et al., 2003a), and INTEX-NA (Singh et al., 2006; Fried et al., 2008a, b). TRACE-P measurements covered the northern Pacific between February and April 2001 and INTEXNA covered North America and North Atlantic during summer 2004. Note that all the formaldehyde measurements used for comparison are from the same aircraft instrument: a tunable diode laser absorption spectrometer (TDLAS) (e.g., Wert et al., 2003). HCHO is detected by probing a HCHO line at $2831.6417 \mathrm{~cm}^{-1}$. The line parameters are taken from the HITRAN linelist but the intensity is corrected by $11 \%$ (Fried et al., 1999). The line used by the TDLAS has a corrected intensity of $5.4410^{-20} \mathrm{~cm}^{-1} /\left(\right.$ molecule $\mathrm{cm}^{-2}$ ) at $303 \mathrm{~K}$ and differs by $6 \%$ compared to the new value of $5.7810^{-20} \mathrm{~cm}^{-1} /\left(\right.$ molecule $\left.\mathrm{cm}^{-2}\right)$ at $303 \mathrm{~K}$ of Perrin et al. (2009). This difference remains within the systematic uncertainties $(12.4 \%$ at $2 \sigma$ level) of the TDLAS estimated through various calibration experiments (Gilpin et al., 1997; Fried et al., 2008a, 2002).

The ACE-FTS observations made in the same region and during the period of each aircraft campaign were averaged over 3 years (2004 to 2006) of ACE measurements. For the comparison with the TRACE-P results, 68 ACE-FTS occultations are within the campaign area (not shown): they are relatively well distributed along the flight track regions (Jacob et al., 2003). The sampled mixing ratios are rather homogeneously distributed around the mean except for one or two occultations likely sampling polluted air masses (Fig. 5). We then assume that the mean ACE-FTS HCHO values obtained are representative of climatological background values and can be compared to measurements made during a 
Table 2. Comparison of upper tropospheric HCHO mixing ratios derived from ACE-FTS and from airborne tunable diode laser measurements performed during two different campaigns. The ACE-FTS vmrs averaged over 2004 to 2006 for the time period corresponding to airborne measurements and the $1 \sigma$ standard deviations are indicated as well as the number of points $(n)$ used for the average. The relative differences are given with respect to the airborne measurements.

\begin{tabular}{|c|c|c|c|c|}
\hline Altitude $(\mathrm{km})$ & $n$ & ACE (pptv) & TDL (pptv) & $(\mathrm{ACE}-\mathrm{TDL})(\%)$ \\
\hline \multicolumn{5}{|c|}{ INTEX - summer 2004 - North America - North Atlantic (Fried et al., 2008b) } \\
\hline $6-8$ & 25 & $131 \pm 48$ & 156 & -16 \\
\hline $8-10$ & 41 & $115 \pm 50$ & 131 & -12 \\
\hline $10-12$ & 46 & $81 \pm 48$ & 95 & -15 \\
\hline \multicolumn{5}{|c|}{ TRACE-P - winter/spring 2001 - Pacific (Singh et al., 2004; Fried et al., 2003a) } \\
\hline $6-8$ & 85 & $83 \pm 55$ & $83^{\mathrm{a}}$ & 0 \\
\hline $8-10$ & 113 & $60 \pm 50$ & $69^{\mathrm{a}}$ & -13 \\
\hline $10-12$ & 129 & $47 \pm 48$ & $51^{\mathrm{a}}$ & -8 \\
\hline $8-12$ & 242 & $53 \pm 49$ & $60^{\mathrm{b}}$ & -12 \\
\hline
\end{tabular}

${ }^{a}$ the reference vmrs are from Singh et al. (2004). ${ }^{b}$ the reference vmrs are from Fried et al. (2003a).

different year. A good agreement $(<13 \%)$ is obtained between ACE-FTS and TDLAS measurements given the errors in the measurements and the difference in the type of measurements (Table 2). Aircraft measurements are in-situ measurements that sample on a finer temporal and spatial scale than remote sensing measurements like those of the ACEFTS. Except in the 6-8 km layer, ACE-FTS mixing ratios are systematically smaller. For the comparison with the INTEXNA results, the number of ACE-FTS occultations considered is smaller: only 23 occultations over the 3 years are sampled. Figure 5 shows that ACE-FTS measurements are more representative of background values than the TDLAS in situ measurements whose flight tracks were often driven by the search for plumes and convection. No strongly enhanced mixing ratios as reported by Fried et al. (2008a, b) are measured by ACE. We then used the HCHO measurements reported by Fried et al. (2008b) and classified as measurements in background air masses for the comparison with ACE-FTS observations. Fried et al. (2008b) defined thresholds for HCHO vmrs (165 pptv) and various tracer species like CO, methane, ethane or methanol (Table 1 of Fried et al., 2008b) to determine background conditions. The formaldehyde mixing ratios measured by the ACE-FTS and the TDLAS are then in relatively good agreement: between 12 and 16\% depending on the altitude, with ACE-FTS values systematically smaller as for the comparison with TRACE-P (Table 2). It is interesting to note that, if thresholds of Fried et al. (2008b) for CO, $\mathrm{C}_{2} \mathrm{H}_{6}$ and $\mathrm{CH}_{3} \mathrm{OH}$ vmrs (also measured by the ACE-FTS) are used to classified ACE-FTS measurements as background or polluted, a significant number of the ACE-FTS measurements would be classified as polluted but with $\mathrm{CO}$ vmrs in the lowest part of the "polluted range". CO vmr values measured by ACE-FTS do not exceed 120 ppbv and are mainly smaller than 100 ppbv.
Table 3. Comparison of the lower stratospheric partial (12-20 km) columns $\left(10^{14}\right.$ molecule $\left./ \mathrm{cm}^{2}\right)$ observed by MIPAS and ACE-FTS. The relative differences are given with respect to MIPAS column.

\begin{tabular}{lcc}
\hline MIPAS & ACE-FTS & (ACE-MIPAS) $(\%)$ \\
\hline & & \\
SON 2003 & SON 2004: $(1.14 \pm 0.48)$ & -25 \\
$(1.52 \pm 0.35)$ & SON 2005: $(0.92 \pm 0.37)$ & -39 \\
& SON 2006: $(1.33 \pm 0.83)$ & -12 \\
& & Total: -26 \\
\hline
\end{tabular}

As mentioned previously rigorous quantitative comparisons between in-situ aircraft measurements and satellite remote sensing measurements are difficult due to the difference in representivity of the measurements but the comparisons show the good reliability of our measurements with the ACEFTS systematically smaller (10-15\%) than the TDLAS. The agreement with aircraft measurements remains very satisfactory $(<15 \%)$ for such a difficult retrieval with significant error estimates (mostly $<40 \%$ ).

\subsection{MIPAS-Envisat}

The MIPAS (Michelson Interferometer for Passive Atmospheric Sounding) spectrometer onboard the Envisat satellite (Fischer et al., 2008) measures formaldehyde profiles from the upper troposphere (above $10 \mathrm{~km}$ ) to the stratosphere (Steck et al., 2008). The $5.7 \mu \mathrm{m}$ spectral region (Perrin et al., 2003) is used for the retrieval. Steck et al. (2008) provided a comparison between the partial zenith column between 12 and $20 \mathrm{~km}$ measured with MIPAS and the same column estimated from the first reported $\mathrm{HCHO}$ measurement from ACE-FTS inside a tropical biomass burning plume (Coheur 


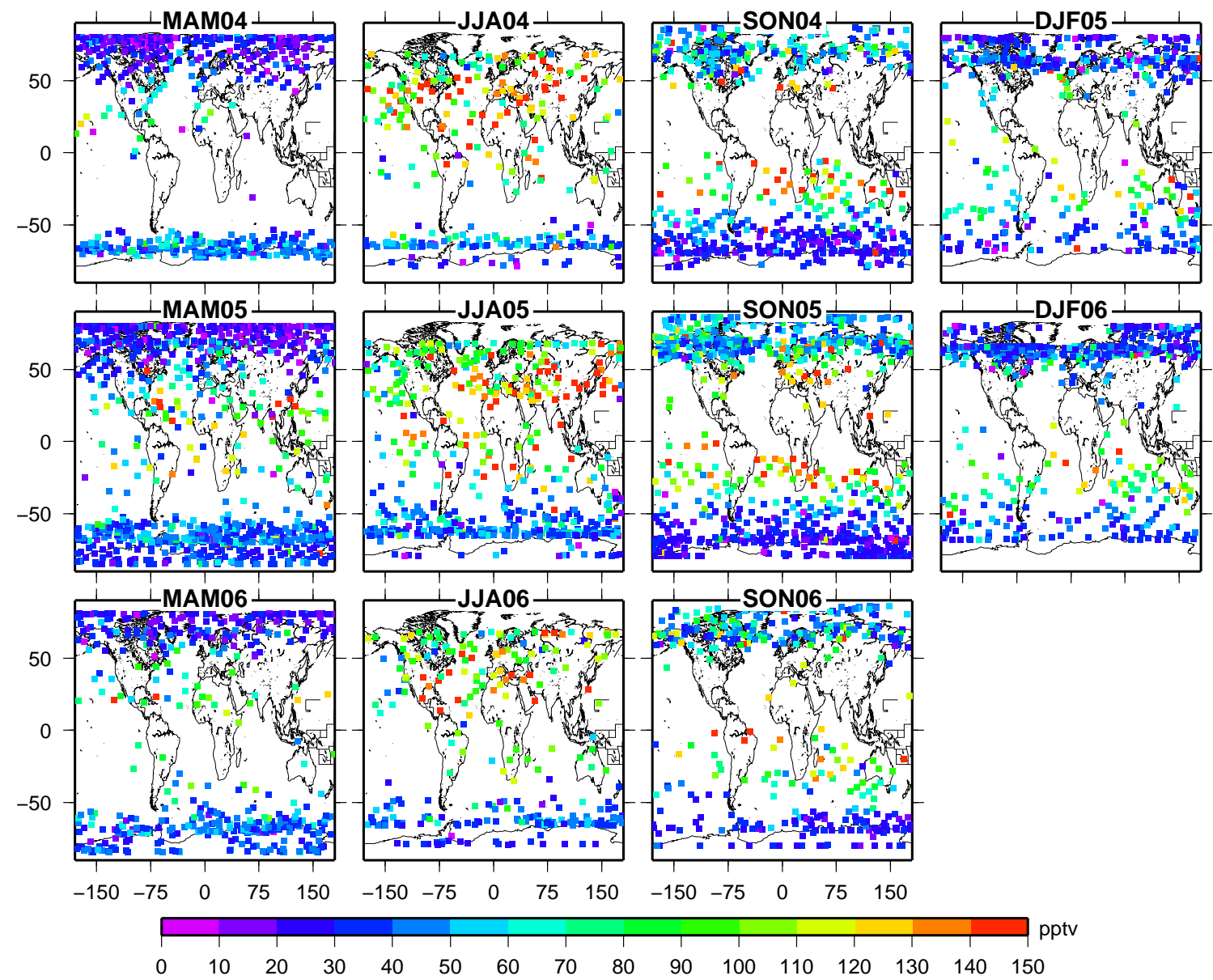

Fig. 6. Upper tropospheric $(6-9 \mathrm{~km})$ formaldehyde volume mixing ratios observed by the ACE-FTS for each season from March 2004 to November 2006.

et al., 2007). We use the zonal partial column at $10^{\circ} \mathrm{N}$ reported in Steck et al. (2008) for the September to November (SON) 2003 period to compare with the mean zonal ACEFTS column of HCHO calculated for the same altitude range, the SON seasons of 2004, 2005 and 2006, and for a latitude band between $10^{\circ} \mathrm{S}$ and $10^{\circ} \mathrm{N}$. The results are summarized in Table 3. The mean difference between $\mathrm{HCHO}$ from ACE-FTS and MIPAS is $26 \%$ with $\mathrm{HCHO}$ smaller for ACE-FTS than for MIPAS. The same tendency to underestimate formaldehyde in the upper troposphere (Sect. 3.1) is observed in the stratosphere. Nevertheless, the difference remains within the standard deviation of the ACE-FTS and MIPAS partial columns and it is not possible to firmly conclude that the ACE-FTS underestimates formaldehyde. Moreover, the sampling and the year of the measurements are different and this likely explains part of the difference. In addition, the $12-20 \mathrm{~km}$ region is not the most favorable altitude range for the ACE-FTS retrieval with a total error that exceeds $100 \%$ (Fig. 4). Although the two instruments do not use the same HCHO spectral bands for their retrieval, Perrin et al. (2009) show a good consistency between the two spectral regions. The $5.7 \mu \mathrm{m}$ region used by MIPAS is certainly better for the retrieval of $\mathrm{HCHO}$ in the stratosphere than the $3.6 \mu \mathrm{m}$ region used by ACE-FTS. An extension of the retrieval to higher in the stratosphere is planned with the ACE-FTS using the $5.7 \mu \mathrm{m}$ band. Adding microwindows from this region would improve the current ACE-FTS retrieval in the $12-20 \mathrm{~km}$ region and would increase the altitude range for comparison with MIPAS.

\section{ACE-FTS HCHO observations}

We present here formaldehyde observations from March 2004 to November 2006 obtained from ACE-FTS with the method described in Sect. 2. Only the occultations that sample low in the troposphere are considered, i.e. below $9 \mathrm{~km}$ and $11 \mathrm{~km}$ in extra-tropical and tropical regions, respectively. The quality of the retrieval has been checked for each occultation and outliers have been discarded (e.g., large negative vmrs). The results are discussed in terms of seasonal means 


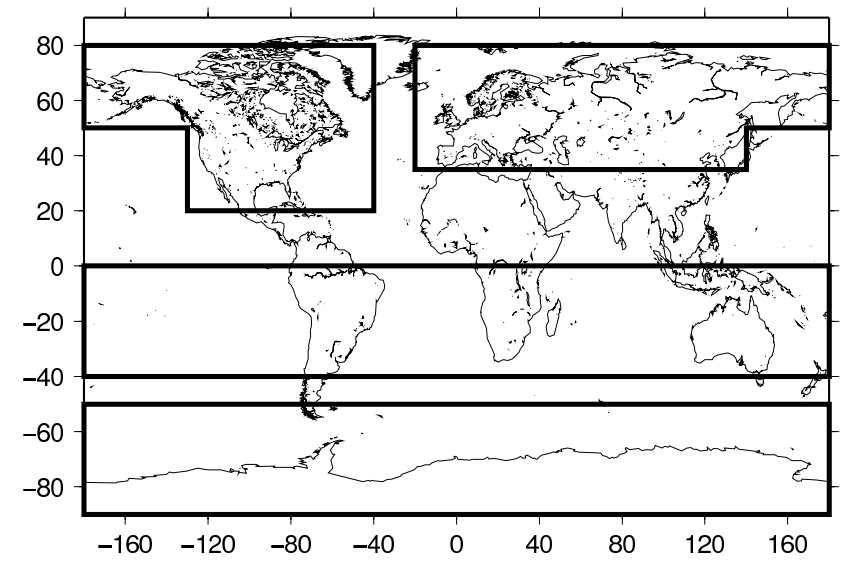

Fig. 7. Regions considered for the detailed study of the seasonal cycle of upper tropospheric formaldehyde.

or distributions. The seasons are defined as follows: MarchApril-May (MAM), June-July-August (JJA), SeptemberOctober-November (SON), and December-January-February (DJF).

Figure 6 displays the seasonal upper tropospheric distributions of HCHO retrieved with ACE-FTS. The vmrs shown in Fig. 6 correspond to the mean vmrs for the $6-9 \mathrm{~km}$ altitude range. Figure 6 shows that the sampling of the ACE-FTS is not uniformly distributed in space and time. The spatial coverage is larger in the mid-to-high latitudes (Fig. 1 and Fig. 1 in Bernath et al., 2006). The rather limited temporal and spatial sampling in the tropics has to be considered in the interpretation of the results. The low sampling of the tropics can lead to a lack of representativeness of the observations for this region.

The HCHO vmrs range from 20-30 pptv to about $150 \mathrm{pptv}$ on average, depending of the season and the location. Large values are observed in the southern tropics and subtropics especially during the JJA and SON periods near Africa and South America. They may partly reflect the impact of biomass burning in the upper troposphere through either the direct injection of emitted $\mathrm{HCHO}$ or of precursors emitted by fires. It is worth noting that enhanced concentrations of $\mathrm{CO}, \mathrm{HCN}$ and $\mathrm{CH}_{3} \mathrm{OH}$ attributed to biomass burning emissions are also detected with the ACE-FTS during SON 2004 (Rinsland et al., 2005; Dufour et al., 2006). The lifetime of $\mathrm{HCHO}$ is short but the correlation with $\mathrm{CO}$ for the same period remains significant (0.65) and likely reveals the biomass burning imprint in this region. The large values observed may also reflect the enhanced $\mathrm{HCHO}$ production due to increased biogenic emissions during the dry season. HCHO values smaller than during JJA and SON are observed during the other seasons (DJF and MAM) but the sampling is limited and does not allow a firm conclusion to be drawn.

In the mid-to-high latitudes of the Southern Hemisphere, formaldehyde concentrations are smaller than $60 \mathrm{pptv}$ and of the order of $40 \mathrm{pptv}$ on average without any strong sea- sonal variations (Fig. 6). These concentrations are mainly representative of background upper tropospheric formaldehyde produced by methane oxidation.

This is in contrast to the significant seasonal variations seen in the mid-to-high latitudes of the Northern Hemisphere (Fig. 6). At these latitudes, volume mixing ratios as low as $30 \mathrm{pptv}$ are observed during winter (DJF-MAM). They reach values of around $150 \mathrm{pptv}$ at a number of locations in summer (JJA) and decrease in fall (SON) to $\sim 60 \mathrm{pptv}$. Formaldehyde values retrieved in winter/spring correspond to background values (of the order of the southern hemispheric values). The maximum observed in the $\mathrm{HCHO}$ distribution in summer is likely related to the maximum in biogenic emissions especially of HCHO precursors like methanol and methyl hydrogen peroxide, and potentially the secondary products from isoprene oxidation. In combination with the increase of convection during summer, this allows the transport of $\mathrm{HCHO}$ precursors to the upper troposphere.

In order to study the temporal variations of $\mathrm{HCHO}$ distributions in more detail, we focus on different regions (North America, Europe-Russia, a south tropical and subtropical latitude band and a mid-to-high latitude band in the Southern Hemisphere, see Fig. 7). Note that the interannual variability that can be deduced from Fig. 6 has to be considered with caution due to the sampling differences between the different years especially in the southern tropics and subtropics. Note also that the uneven sampling of the data can slightly affect the seasonal cycle derived for each region. However, we ensured (by analysis of the model results) that this potential bias is lower than the observational errors. The seasonal variations of the mean vmrs at two altitudes ( 6.5 and $8.5 \mathrm{~km})$ are given in Fig. 8 (in red). The two regions of the Northern Hemisphere have a maximum in summer with similar intensities for the 3 years. No significant differences can be noted between the two continents. The mean winter values correspond to background production of HCHO. Formaldehyde decreases with altitude but displays a similar seasonal variation. This seasonal cycle is clearly visible up to $12.5 \mathrm{~km}$ in the ACE-FTS data (not shown).

The magnitude of the variation between seasonal means is weak in the $50^{\circ} \mathrm{S}-90^{\circ} \mathrm{S}$ latitude band (Fig. 8). Nevertheless, a minimum that seems significant (slightly larger than the error bars) is observed in SON for the both altitudes. That might reflect the influence of the variation of the radiation during the year - the maximum taking place during summer (SON-DJF for the Southern Hemisphere) - and then the maximum of destruction of background formaldehyde (Fig. 9).

As mentioned previously the lack of in sampling in the southern tropics and subtropics (Fig. 6) does not allow a firm conclusion to be made concerning the potential temporal variation of the $\mathrm{HCHO}$ distribution. However, the tendency given by the observations look consistent with what is expected. The mean vmr over the 2004-2006 period is larger than at other latitudes as expected. This likely reflects a larger production of $\mathrm{HCHO}$ from non methane hydrocarbons 

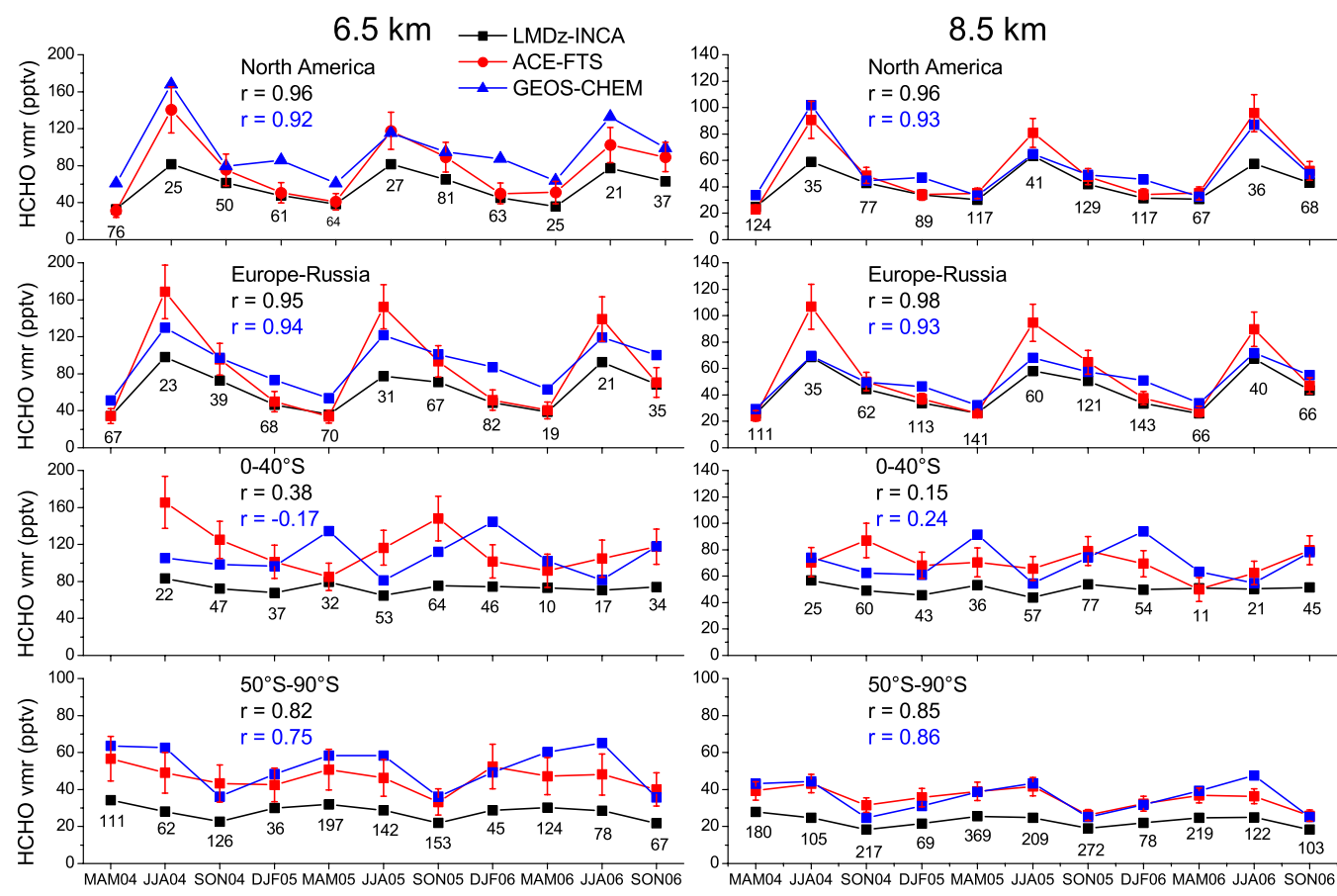

Fig. 8. Seasonal variations of observed (red) and simulated (blue for GEOS-Chem and black for LMDz-INCA) formaldehyde mixing ratios at 6.5 and $8.5 \mathrm{~km}$ averaged for different regions. The temporal correlation (noted $r$ ) is indicated in each panel with the same color code.

Table 4. Global Terrestrial Emissions considered by the two global models for the year 2005 and methane tropospheric mixing ratios used in the models.

\begin{tabular}{cccc}
\hline Source & Species & GEOS-Chem & LMDz-INCA \\
\hline Anthropogenic & $\mathrm{NO}_{\mathrm{x}}(\mathrm{TgN} / \mathrm{yr})$ & 25.3 & 24.0 \\
& $\mathrm{CO}(\mathrm{Tg} / \mathrm{yr})$ & 371.1 & 308.8 \\
& $\mathrm{CH}_{4}(\mathrm{Tg} / \mathrm{yr})$ & $\mathrm{nc}$ & 92.4 \\
& $\mathrm{VOC}(\mathrm{TgC} / \mathrm{yr})$ & 50.6 & 53.1 \\
& & 7.5 & 7.3 \\
Biomass Burning (including & $\mathrm{NO}_{\mathrm{x}}(\mathrm{TgN} / \mathrm{yr})$ & 577.5 & 554.2 \\
biofuel emissions) & $\mathrm{CO}(\mathrm{Tg} / \mathrm{yr})$ & $\mathrm{nc}$ & 30.9 \\
& $\mathrm{CH}(\mathrm{Tg} / \mathrm{yr})$ & 31.0 & 59.1 \\
& $\mathrm{VOC}(\mathrm{TgC} / \mathrm{yr})$ & & 647.9 \\
Biogenic & $\mathrm{VOC}(\mathrm{TgC} / \mathrm{yr})$ & 581.4 & 357.0 \\
$\mathrm{Natural}$ (wetland, soil, rice & $\mathrm{CH}(\mathrm{Tg} / \mathrm{yr})$ & $\mathrm{nc}$ & \\
termites, animals) & & & 1624 \\
$\mathrm{CH}_{4}$ mixing ratios (ppbv) & $\mathrm{Global}$ & 1751 & 1687 \\
& $90 \mathrm{~N}-30 \mathrm{~N}$ & 1822 & 1643 \\
& $30 \mathrm{~N}-0 \mathrm{~N}$ & 1767 & 1589 \\
& $0 \mathrm{~S}-30 \mathrm{~S}$ & 1709 & 1578 \\
\hline
\end{tabular}

in the tropics due to sustained biogenic emissions of $\mathrm{HCHO}$ precursors during the entire year in this region (Fig. 9). The peak of $\mathrm{HCHO}$ during the biomass burning period is more pronounced at $6.5 \mathrm{~km}$ compared to $8.5 \mathrm{~km}$ (Fig. 9).

\section{Comparison with two state-of-the-art CTMs}

The aim of the comparison with the two models, GEOSChem (Bey et al., 2001) and LMDz-INCA (Hauglustaine et 
Budget terms

(sum over the 19 INCA vertical levels)
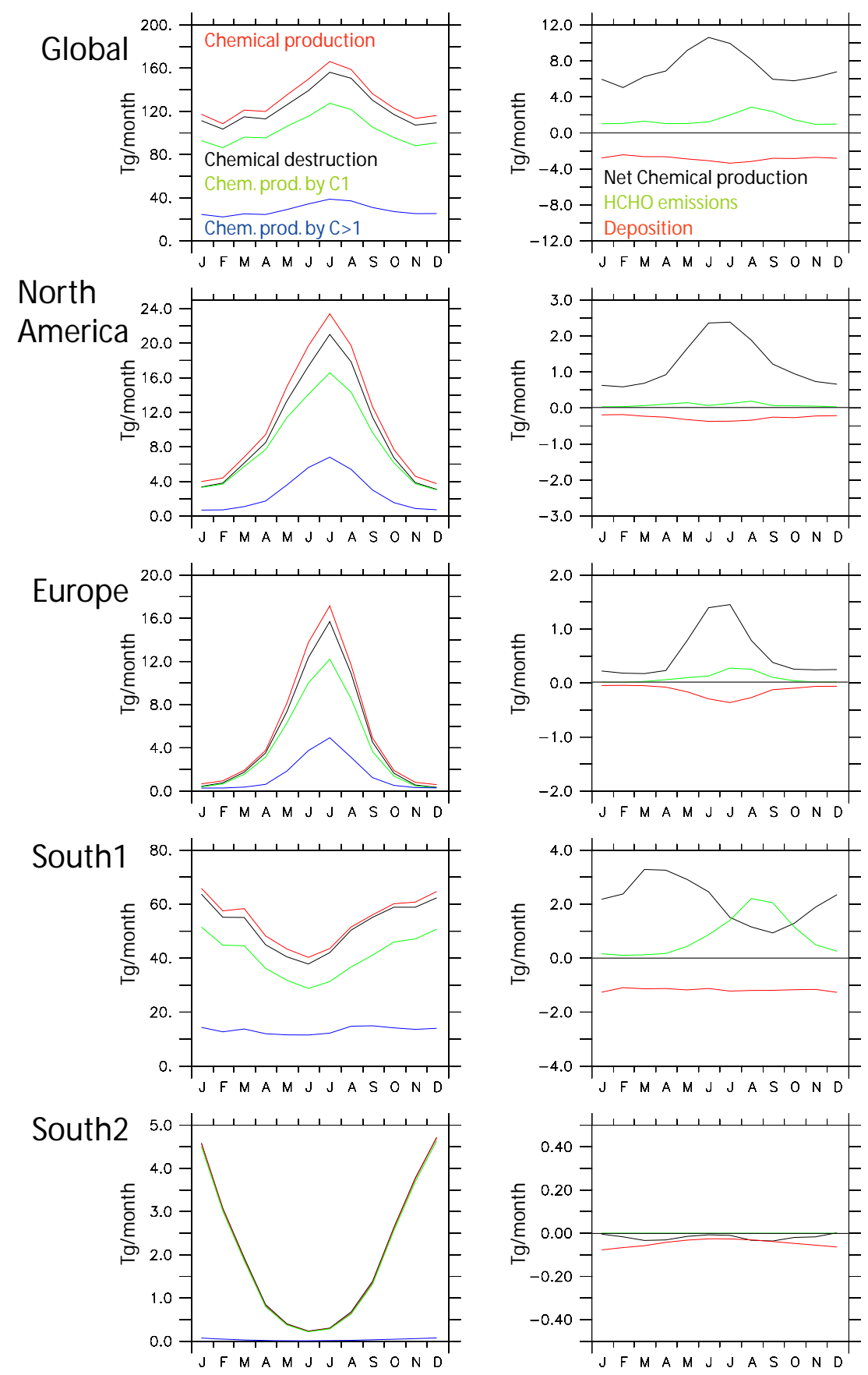

Fig. 9. Seasonal cycle of the chemical budget terms for the entire Earth and the same regions defined in Fig. 7 and Table 5 (left): the chemical production is separated into direct production from the compounds with one carbon atom $(\mathrm{C} 1)$ and compounds with more than one carbon atom $(\mathrm{C}>1)$. The primary emissions of $\mathrm{HCHO}$ and the deposition are compared with the net chemical production on the right. The "South 1 " and "South 2 " regions correspond to the $0-40^{\circ} \mathrm{S}$ and the $50^{\circ} \mathrm{S}-90^{\circ} \mathrm{S}$ latitude bands, respectively. 


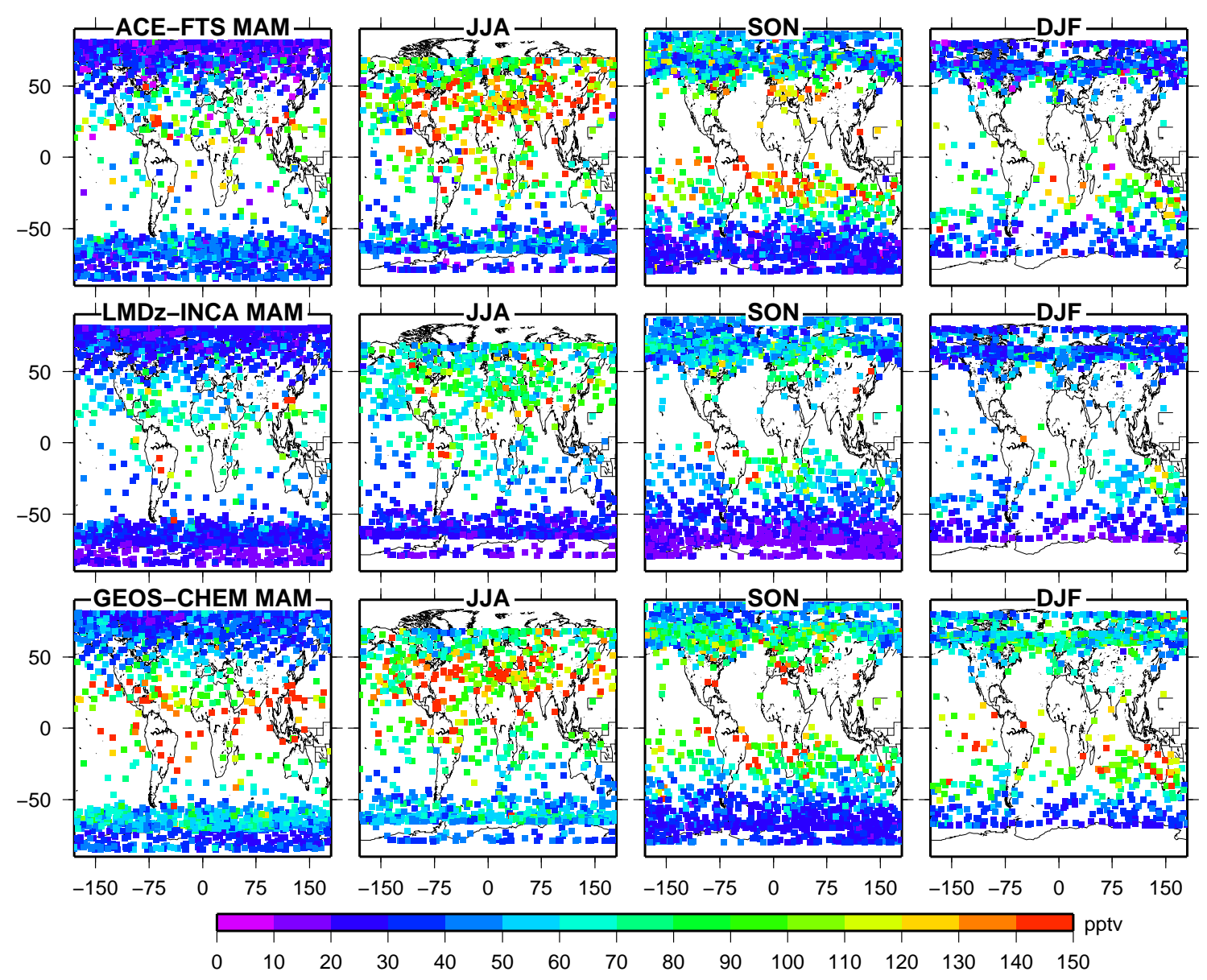

Fig. 10. Upper tropospheric $(6-9 \mathrm{~km})$ formaldehyde volume mixing ratios observed by the ACE-FTS (top) and simulated by LMDz-INCA (middle) and GEOS-Chem (bottom) for each season from March 2004 to November 2006. Measurements for the 3 years are displayed in the same panel for each season. The modeled vmrs are interpolated to the measurement locations.

al., 2004), is to give a picture of our current understanding of upper tropospheric chemistry with a new set of data that gives new insight on the seasonal variation of upper tropospheric $\mathrm{HCHO}$ (especially in the mid-to-high latitudes), keeping in mind the uncertainties and the discrepancies remaining in the models.

Note that a detailed investigation of the reasons for model discrepancies is beyond the scope of this paper; only suggestions for these differences will be made in the present study.

\subsection{GEOS-Chem}

GEOS-Chem (v7.04; http://www-as.harvard.edu/chemistry/ trop/geos/) is a global 3-D chemistry transport model able to simulate tropospheric trace gas and aerosol distributions (Bey et al., 2001). The model contains a detailed $\mathrm{O}_{3}-\mathrm{NO}_{\mathrm{x}}-$ VOC-aerosol reaction scheme that is forced with assimilated meteorological data from the Goddard Earth Observing System 4 (GEOS-4), of the NASA Global Modelling and Assim- ilation Office (GMAO). The GEOS-4 data have a 6-hourly temporal resolution (3-hours for surface variables and mixing depths) and a $1^{\circ} \times 1.25^{\circ}$ (latitude $\times$ longitude) horizontal resolution. In this study we degrade the horizontal resolution of the GEOS- 4 data to $2^{\circ} \times 2.5^{\circ}$ and the vertical resolution to 30 eta levels (levels above $\sim 50 \mathrm{hPa}$ are lumped together).

The GEOS-Chem chemical mechanism (originally based on Horowitz et al., 1998) provides a relatively detailed simulation of gas phase $\mathrm{O}_{3}-\mathrm{NO}_{\mathrm{x}}$-hydrocarbon chemistry $(\sim 80$ species, 300 reactions) integrated using the SMVGEARII solver of Jacobson (1995). The scheme contains an explicit treatment of the photo-oxidation pathways for five nonmethane hydrocarbons (ethane, isoprene, lumped $>\mathrm{C}_{3}$ alkanes, lumped $>\mathrm{C}_{2}$ alkenes and propane) and includes recycling of organic peroxides (Palmer et al., 2003). Production of HCHO from the oxidation of $\alpha$ and $\beta$-pinene, and methylbutenol (MBO), is parameterized using Master Chemical Mechanism calculations (Palmer et al., 2006). 


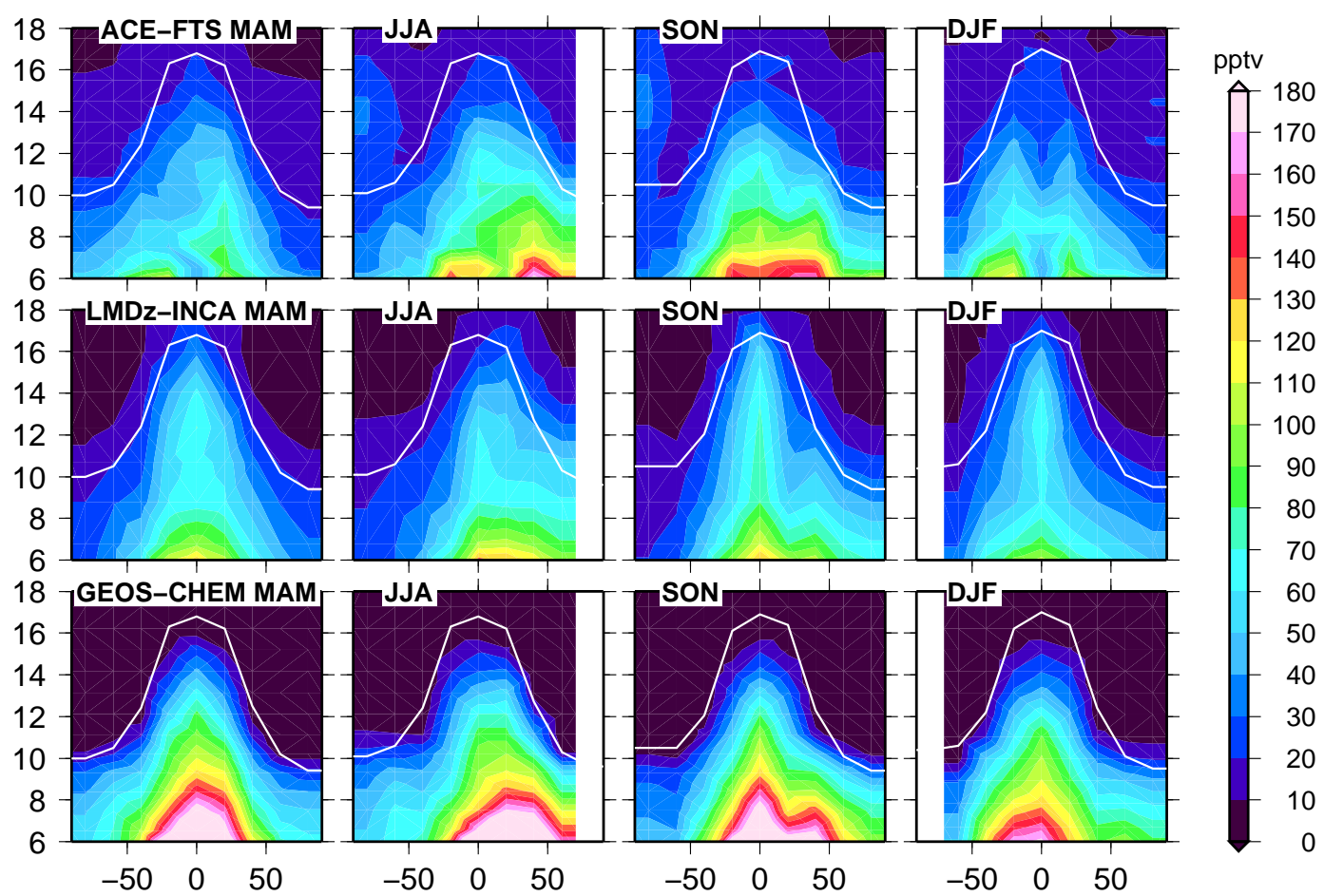

Fig. 11. Zonal mean HCHO volume mixing ratio profiles observed by the ACE-FTS (top) and simulated with the LMDz-INCA (middle) and GEOS-Chem (bottom) models averaged over each season from March 2004 to November 2006. The modeled profiles used are interpolated to the measurement locations. The number of profiles averaged in each $20^{\circ}$ latitude band is larger than 20 . A mean tropopause height is calculated based on NCEP meteorological values (white line).

Biomass burning emissions of $\mathrm{HCHO}$ and 14 other species are parameterized using the Global Fire Emission Database version 2 (GFEDv2) (Giglio et al., 2006; van der Werf et al., 2006). Biogenic emissions (isoprene, monoterpenes and MBO) are based on the MEGAN model (Guenther et al., 2006), with isoprene emissions over tropical South America scaled down by $\sim 30 \%$ (Barkley et al., 2008b). Global anthropogenic emissions (scaled to 2004) are based on the GEIA (Benkovitz et al., 1996) and EDGAR 3.2 FT2000 (www.rivm.nl/edgar/model/v32ft2000edgar) (for $\mathrm{NO}_{\mathrm{x}}, \mathrm{CO}$ and $\mathrm{SO}_{2}$ only; Oliver et al., 2001) inventories. Regional emission inventories are used over Asia, Europe, Mexico and the US (Dunlea et al., 2008, and references therein). A summary of the annual emission totals for 2005 is given in Table 4. GEOS-Chem uses prescribed average latitudinal methane mixing ratios (based on global NOAA/ESRL observations) assigned to each model grid cell (Table 4).

Dry deposition of aerosols and gases uses a standard resistance-in-series model (Wesely, 1989), as described in Wang et al. (1998). Wet deposition schemes for aerosols and gases are described by Liu et al. (2001) and Mari et al. (2000), respectively.

To simulate the HCHO distributions shown here, the model was initialized by a six month spin up, and then restarted to run from January 2004 to December 2006.

\subsection{LMDz-INCA}

LMDz.3-INCA. 2 is a state-of-the-art global threedimensional chemistry transport model simulating gaseous and aerosol chemistry. $\mathrm{LMDz}$ is a grid point General Circulation Model (GCM) coupled on-line to INCA (Interactive Chemistry and Aerosols) (Hauglustaine et al., 2004; Folberth et al., 2006). The version of INCA used in this study simulates tropospheric chemistry, monthly emissions, and deposition of primary tropospheric trace species including non-methane hydrocarbons. The horizontal resolution is $2.5^{\circ} \times 3.75^{\circ}$ and $19 \sigma-p$ levels are considered from the surface to about $3 \mathrm{hPa}$. The ORCHIDEE (Organizing Carbon and Hydrology in Dynamic Ecosystems) dynamical vegetation model has been used to calculate the seasonal and geographical distribution of biogenic emissions (Lathière et al., 2005). The biomass burning emissions for wild fires are based on the mean of inventories covering the 1997-2001 period provided by van der Werf et al. (2004), rescaled region by region using the MODIS data for 2004 and 2005 (Turquety, private communication, 2006). The primary formaldehyde emissions, mainly due to biomass burning, reach $17 \mathrm{Tg} / \mathrm{yr}$. All the emissions are injected at the lowest level of the model.

The annual emissions for 2005 are summarized and compared to those of GEOS-Chem in Table 4. The emissions of 
$\mathrm{NO}_{\mathrm{x}}$ from anthropogenic sources and biomass burning are similar in the two models. The $\mathrm{CO}$ emissions, both anthropogenic and from biomass burning are larger in GEOS-Chem and the biomass burning and biogenic emissions of VOCs are larger in LMDz-INCA. Some of the difference is certainly related to the rescaling of the isoprene emissions in South America recently recommended by Barkley et al. (2008b) and included in GEOS-Chem. The main difference resides in methane mixing ratios used to constrain the models. The difference is only $7 \%$ but as methane oxidation is the predominant source of HCHO (Pfister et al. 2008; Stavrakou et al., 2009), this difference may imply significant differences in simulated $\mathrm{HCHO}$ vmr.

\subsection{Seasonality of the HCHO budget terms}

The chemical production and loss of $\mathrm{HCHO}$ as calculated by the LMDz-INCA model, as well as the primary emissions and the deposition of HCHO are displayed in Fig. 9 for the same regions as defined in Fig. 8. A total formaldehyde photochemical production of $1565 \mathrm{Tg} / \mathrm{year}$ from hydrocarbon and methane oxidation is found. The photochemical destruction is $1479 \mathrm{Tg} /$ year and the surface dry deposition accounts for $34 \mathrm{Tg} /$ year. Note that the primary emissions of $\mathrm{HCHO}$ are very small compared to the secondary production. In Fig. 9, the chemical production by oxidation of $\mathrm{C} 1 \mathrm{com}-$ pounds (with a single carbon atom) is separated from the direct chemical production of $\mathrm{HCHO}$ from oxidation of hydrocarbons with more than one carbon atom ( $\mathrm{C}>1$ compounds). Globally the net chemical production of $\mathrm{HCHO}$ is positive and larger during summer months. This is particularly true in the Northern Hemisphere. In the southern tropics and subtropics, the chemical production dominates except during the fire season when the primary emissions of $\mathrm{HCHO}$ are significant. The chemical production in high southern latitudes is small compared to other latitudes (Fig. 9). This region constitutes a chemical sink for formaldehyde and mostly reflects the $\mathrm{HCHO}$ chemistry in remote area dominated by $\mathrm{CH}_{4}$ oxidation. Except for these latitudes, the secondary production of formaldehyde by $\mathrm{C}>1$ compounds (mainly biogenic species like isoprene) represent about $22 \%$ of the total production in agreement with previous studies (Pfister et al., 2008; Stavrakou et al., 2009) and can reach up to 50\% in the US and Europe during summer. The role of biogenic compounds is then clearly significant in the HCHO production and partly drives the seasonality of the formaldehyde distributions. Calculations that integrate over the upper troposphere reveal that this region is a chemical sink for formaldehyde (not shown). The variations observed in the ACE-FTS retrieved mixing ratios thus reflect chemical production in lower layers and the impact of transport.

\subsection{Results and discussion}

As the interannual variations seem to be relatively weak (Sect. 4), we provide average seasonal results over the 3 years of analyzed observations and display all the data from the 3 years in a single plot to show the horizontal distribution. Figure 10 compares the upper tropospheric seasonal distribution of HCHO (mean vmrs between 6 and $9 \mathrm{~km}$ ). The seasonal variations observed with ACE-FTS are roughly reproduced by the models with a maximum in summer for the mid-to-high northern latitudes and with large $\mathrm{HCHO} v \mathrm{vmr}$ values during the biomass burning period in the southern tropics and subtropics. The main differences to be noted in Fig. 10 are (1) an apparent underestimation of the observed largest values by LMDz-INCA; (2) a large overestimation of the spring (MAM) tropical and subtropical values by GEOS-Chem as well as during winter at high latitudes for both hemispheres. Figure 11 displays the zonal means of formaldehyde profiles for $20^{\circ}$-latitude bands by season for ACE-FTS (top), LMDz-INCA (middle), and GEOS-Chem (bottom). Underestimation by LMDz-INCA and overestimation by GEOS-Chem at the lowest altitudes can clearly be seen in Fig. 11. A difference in the vertical extension of formaldehyde between the two models can also be noted. The vertical gradient of HCHO is stronger in GEOS-Chem compared to LMDz-INCA and ACE-FTS. This difference might be due to a difference in the vertical transport in the two models and also to the fact that the stratosphere is treated differently (and not correctly) in the two models.

Figure 8 provides a detailed comparison of the seasonal variations simulated by GEOS-Chem and LMDz-INCA, and observed by ACE-FTS for different regions at two altitudes $(\sim 6.5$ and $8.5 \mathrm{~km})$. The comparisons are quantified on average for each season for the $8.5 \mathrm{~km}$ altitude (representative of the upper troposphere) in Table 5. The number $n$ of ACEFTS measurements are indicated with the mean volume mixing ratios observed and simulated by the two models. Statistical parameters are given: biases, RMSE (root mean square of the errors) and correlation coefficients. The mean bias (noted Bias in Table 5) and the mean absolute bias (noted |bias| in Table 5) are defined in Eq. (1) and (2), respectively.

$$
\begin{gathered}
\text { Bias }=\frac{\text { meanVMRmodel }- \text { meanVMRobs }}{\text { meanVMRobs }_{10}} \times 100 \\
\mid \text { bias } \mid=\frac{\frac{1}{n} \sum_{i} \mid \text { VMRmodel }_{\mathrm{i}}-\text { VMRobs }_{i} \mid}{\text { meanVMRobs }} \times 100
\end{gathered}
$$

GEOS-Chem succeeds in reproducing the summer maximum observed over North America (Bias $=6 \%$, Table 5) whereas LMDz-INCA underestimates it (Bias $=\sim 30 \%$ ) but the mean absolute bias and the RMSE are larger for GEOS-Chem, revealing more compensation effects on the average. In contrast, GEOS-Chem overestimates winter/spring HCHO values $(\sim 35 \%)$ and LMDz-INCA reproduces well these small 
Table 5. Statistics derived from the comparison between ACE-FTS observations and simulations of LMDz-INCA and GEOS-Chem expressed in vmr (pptv) at $8.5 \mathrm{~km}$ by season and for different regions: $\mathrm{n}$ is the number of data considered; the mean bias and the mean absolute bias (|bias $\mid$ ) defined in the text are reported as well as the root mean square of error (RMSE) and the spatial correlation $(r)$. Mean biases smaller than $20 \%$ and correlation coefficients larger than 0.5 are in bold.

\begin{tabular}{|c|c|c|c|c|c|c|c|c|c|c|c|c|c|}
\hline Region & Period & $n$ & $\begin{array}{c}\text { ACE-FTS } \\
\text { vmr }\end{array}$ & \multicolumn{5}{|c|}{ LMDz-INCA } & \multicolumn{5}{|c|}{ GEOS-Chem } \\
\hline global & full & 5025 & 46 & 34 & -26 & 39 & 74 & 0.54 & 46 & 2 & 47 & 87 & 0.39 \\
\hline \multirow[t]{5}{*}{ North America ${ }^{a}$} & full & 900 & 44 & 38 & -15 & 36 & 57 & 0.63 & 47 & 7 & 55 & 80 & 0.40 \\
\hline & MAM & 308 & 30 & 28 & -7 & 37 & 58 & 0.66 & 34 & 11 & 61 & 90 & 0.35 \\
\hline & JJA & 112 & 89 & 60 & -32 & 43 & 59 & 0.28 & 84 & -6 & 51 & 71 & 0.17 \\
\hline & SON & 274 & 49 & 43 & -13 & 31 & 44 & 0.57 & 48 & -2 & 55 & 74 & 0.10 \\
\hline & DJF & 206 & 34 & 33 & -5 & 32 & 43 & 0.26 & 46 & 35 & 51 & 67 & 0.17 \\
\hline \multirow[t]{5}{*}{ Europe Russia $^{a}$} & full & 958 & 47 & 39 & -17 & 38 & 67 & 0.59 & 48 & 2 & 50 & 77 & 0.44 \\
\hline & MAM & 318 & 26 & 26 & 2 & 35 & 47 & 0.59 & 31 & 23 & 57 & 81 & 0.40 \\
\hline & JJA & 135 & 96 & 64 & -34 & 42 & 52 & 0.28 & 70 & -28 & 45 & 73 & 0.10 \\
\hline & SON & 249 & 56 & 47 & -16 & 38 & 70 & 0.32 & 55 & -3 & 46 & 73 & 0.30 \\
\hline & DJF & 256 & 37 & 33 & -11 & 36 & 68 & 0.36 & 49 & 31 & 57 & 85 & 0.22 \\
\hline \multirow[t]{5}{*}{ Latitude band: $0-40^{\circ} \mathrm{S}$} & full & 431 & 73 & 49 & -33 & 46 & 61 & 0.42 & 73 & -1 & 46 & 70 & 0.32 \\
\hline & MAM & 49 & 65 & 53 & -19 & 50 & 80 & 0.10 & 84 & 29 & 61 & 90 & 0.14 \\
\hline & JJA & 103 & 66 & 49 & -26 & 51 & 71 & 0.30 & 60 & -10 & 43 & 66 & 0.26 \\
\hline & SON & 182 & 82 & 50 & -39 & 45 & 56 & 0.66 & 72 & -12 & 40 & 63 & 0.45 \\
\hline & DJF & 97 & 69 & 46 & -33 & 40 & 50 & 0.49 & 81 & 17 & 55 & 77 & 0.10 \\
\hline \multirow[t]{5}{*}{ Latitude band: $50^{\circ} \mathrm{S}-90^{\circ} \mathrm{S}$} & full & 1943 & 35 & 23 & -35 & 42 & 98 & 0.17 & 36 & 1 & 37 & 98 & 0.10 \\
\hline & MAM & 768 & 38 & 26 & -33 & 40 & 84 & 0.14 & 40 & 4 & 38 & 85 & 0.00 \\
\hline & JJA & 436 & 41 & 25 & -38 & 42 & 53 & 0.46 & 45 & 11 & 32 & 53 & 0.20 \\
\hline & SON & 592 & 28 & 18 & -35 & 44 & 150 & 0.10 & 25 & -12 & 39 & 148 & 0.00 \\
\hline & DJF & 147 & 34 & 21 & -38 & 45 & 126 & 0.00 & 31 & -9 & 43 & 126 & 0.10 \\
\hline
\end{tabular}

a North America: $\left(50-80^{\circ} \mathrm{N} ; 180-40^{\circ} \mathrm{W}\right)+\left(20-50^{\circ} \mathrm{N} ; 130-40^{\circ} \mathrm{W}\right)$;

Europe-Russia: $\left(50-80^{\circ} \mathrm{N} ; 20^{\circ} \mathrm{W}-180^{\circ} \mathrm{E}\right)+\left(35-50^{\circ} \mathrm{N} ; 20^{\circ} \mathrm{W}-140^{\circ} \mathrm{E}\right)$

values close to background levels $(\sim 5 \%)$ with a smaller RMSE and mean absolute bias. In Europe-Russia, both models fail to capture the maximum in summer especially at $8.5 \mathrm{~km}$ and are about $30 \%$ smaller than the observed ones (Fig. 8). Mean absolute biases are similar whereas the RMSE is larger for GEOS-Chem. LMDz-INCA still performs well in winter $(2 \%)$ and GEOS-Chem overestimates winter values by up to $60 \%$ at $6.5 \mathrm{~km}$. The temporal correlation between the simulations and the observations (Fig. 8) is very good in the mid-to-high northern latitudes in the both cases $(r>0.92)$. Note that the emissions used in the two models are different. In particular, the anthropogenic emissions used by GEOS-Chem for North America (EPA 1999 National Emissions Inventory; http://www.epa.gov/ttn/chief/net/) are more up to date compared to the anthropogenic emissions used by LMDz-INCA (Edgar V2). The comparison for these two regions would suggest that the summer emissions of GEOSChem in North America allow the maximum to be reproduced. However, other differences in the models (transport, chemistry) could also partly explain the differences observed between the simulations of the two models. For the high southern latitudes, both models perform well in reproducing the temporal variability $(r \sim 0.80$, Fig. 8$)$ but LMDz-INCA systematically underestimates HCHO $(\sim 35 \%)$. The agreement between ACE-FTS and GEOS-Chem is very good (Table 5). The mean absolute bias is of the order of the observa- tion errors. In the southern tropics and subtropics, the agreement is the worst for both models. They both fail to reproduce the temporal variations as the correlation coefficients are not significant (Fig. 8). These observed variations are not reproduced by LMDz-INCA which has a relatively constant $\mathrm{HCHO}$ vmr. Observations show the influence of biomass burning with larger $\mathrm{HCHO}$ vmrs only during the SON period (Table 5) but both models show maxima during the MAM period. GEOS-Chem predicts a maximum during DJF 2006 not seen in the observations. As for the high southern latitudes, LMDz-INCA systematically underestimates the observations (33\% on average over the year, Table 5). GEOS-Chem reproduces very well the annual $\mathrm{HCHO}$ mean considering the mean bias (Eq. 1).

In conclusion, GEOS-Chem seems to perform better than LMDz-INCA in reproducing HCHO on average, except during winter/spring of the Northern Hemisphere. It should be noted however that the mean absolute bias and RMSE are often larger with GEOS-Chem than with LMDz-INCA. Furthermore, the spatial correlation (Table 5) is generally much poorer between the ACE-FTS and GEOS-Chem (0.39 on average) whereas this correlation is better with LMDzINCA (0.54). Thus, GEOS-Chem performs better on average but is worse in capturing the spatial variations compared to LMDz-INCA. The statistical comparators indicate that GEOS-Chem has more problems than LMDz-INCA in 
reproducing the spatial distribution of $\mathrm{HCHO}$ especially in the Northern Hemisphere. On the other hand, LMDz-INCA reproduces rather well the temporal and spatial variations of HCHO distributions but is biased especially in the Southern Hemisphere. One hypothesis that would perhaps partly explain this systematic bias might be the small methane concentrations calculated in the model (Table 4). Further studies are needed to elucidate the reasons for this bias.

\section{Conclusions}

Almost 3 years of ACE-FTS observations of HCHO from March 2004 to November 2006 on a near-global scale have been analyzed and discussed. An improved spectroscopic linelist has been used for the retrieval of formaldehyde profiles in the $5-25 \mathrm{~km}$ range. The total error in individual $\mathrm{HCHO}$ profiles ranges from 30 to $40 \%$ on average in the upper troposphere and progressively increases with altitude. Comparisons with previous aircraft and satellite (MIPAS) measurements show an overall reasonable agreement between ACE-FTS profiles and independent measurements (within the errors).

The observations give an overview of $\mathrm{HCHO}$ distribution and seasonal variations at different latitudes. A seasonal cycle with a large maximum during summer is observed by the ACE-FTS in the mid-to-high northern latitudes. This cycle likely partly reflects the biogenic emissions of formaldehyde precursors that can be very large during the growing season at northern latitudes (Palmer et al., 2003, 2006). In contrast, the temporal and spatial variations of $\mathrm{HCHO}$ at the high southern latitudes are negligible and $\mathrm{HCHO}$ values observed reflect background conditions (i.e., HCHO mainly produced by methane oxidation). The influence of biomass burning is also visible in ACE-FTS observations of HCHO during September to November in the southern tropics.

Comparisons with two state-of-the-art models (GEOSChem and LMDz-INCA) show that the main global variations are reproduced by the models but not with complete fidelity. GEOS-Chem reproduces well the observations on average (over one year) but has some difficulties in reproducing the spatial variability of the observations. LMDz-INCA is biased in the Southern Hemisphere but better reproduces the temporal and spatial variations of $\mathrm{HCHO}$ distributions as compared to GEOS-Chem. The differences in the ability of the models to reproduce the summer maximum over North America is likely partly linked to the emissions inventories and parameterization used by the models, although it is difficult at this stage to determine which processes are responsible for the discrepancies between the models and between the models and the observations. However, a better agreement between the methane concentrations used in the models would help to improve the comparisons and to assess which processes are responsible of the remaining differences. Many processes are responsible for the HCHO distribution: emis- sions of $\mathrm{HCHO}$ itself but also of various $\mathrm{HCHO}$ precursors, transport (advection, convection), and chemistry and have to be investigated in future work to establish the reason for the differences.

Acknowledgements. The ACE mission is funded primarily by the Canadian Space Agency. NCEP Reanalysis data was provided by the NOAA/OAR/ESRL PSD, Boulder, Colorado, USA, from http://www.cdc.noaa.gov. Support was also provided by the UK Natural Environment Research Council (NERC) for M.P.B. (grant NE/D001471) and P.F.B. The NERC National Centre for Earth Observation (NCEO) is also acknowledged for support. The work of S. Szopa is funded by the EU-FP6-GEOmon project. We thank A. Fried for his helpful comments on TDLAS measurements.

Edited by: R. Volkamer

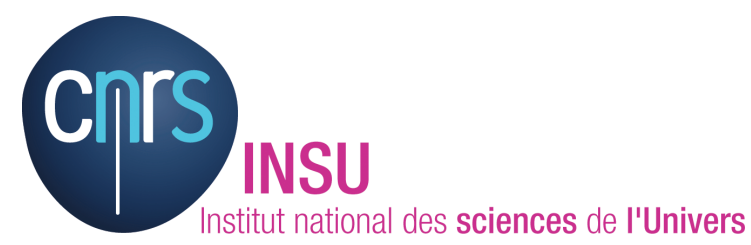

The publication of this article is financed by CNRS-INSU.

\section{References}

Arlander, D. W., Brüning, D., Schmidt, U., and Ehhalt, D. H.: The tropospheric distribution of formaldehyde during TROPOZ II, J. Atmos. Chem., 22, 251-268, 1995.

Atkinson, R.: Gas-phase tropospheric chemistry of organic compounds, J. Phys. Chem. Ref. Data Monogr., 2, 13-46, 1994.

Atkinson, R.: Atmospheric chemistry of VOCs and $\mathrm{NO}_{\mathrm{x}}$, Atmos. Environ., 34, 2063-2101, 2000.

Barkley, M. P., Palmer, P. I., Boone, C. D., Bernath, P. F., and Suntharalingam, P.: Global distributions of carbonyl sulfide in the upper troposphere and stratosphere, Geophys. Res. Lett., 35, L14810, doi:10.1029/2008GL034270, 2008a.

Barkley, M. P., Palmer, P. I., Kuhn, U., Kesselmeier, J., Chance, K., Kurosu, T. P., Martin, R. V., Helmig, D., and Guenther, A.: Net ecosystem fluxes of isoprene over tropical South America inferred from GOME observations of HCHO columns, J. Geophys. Res., 113, D20304, doi:10.1029/2008JD009863, 2008b.

Benkovitz, C. M., Scholtz, M. T., Pacyna, J., Tarrason, L., Dignon, V, Voldner, E. C., Spiro, P. A., Logan, J. A., and Graedel, T. E.: Global gridded inventories of anthropogenic emissions of sulfur and nitrogen, J. Geophys. Res., 101(D22), 29239-29253, 1996.

Bey, I., Jacob, D., Yantosca, R., Logan, J., Field, B., Fiore, A., Li, Q., Liu, H., Mickley, L., and Schultz, M.: Global modeling of tropospheric chemistry with assimilated meteorology: Model description and evaluation, J. Geophys. Res., 106(D19), 23073, doi:10.1029/2001JD000807, 2001.

Bernath, P. F., McElroy, C. T., Abrams, M. C., Boone, C. D., Butler, M., Camy-Peyret, C., Carleer, M., Clerbaux, C., Coheur, P.-F., Colin, R., DeCola, P., DeMazière, M., Drummond, J. R., Dufour, D., Evans, W. F. J., Fast, H., Fussen, D., Gilbert, K., Jennings, D. 
E., Llewellyn, E. J., Lowe, R. P., Mahieu, E., McConnell, J. C., McHugh, M., McLeod, S. D., Michaud, R., Midwinter, C., Nassar, R., Nichitiu, F., Nowlan, C., Rinsland, C. P., Rochon, Y. J., Rowlands, N., Semeniuk, K., Simon, P., Skelton, R., Sloan, J. J., Soucy, M.-A., Strong, K., Tremblay, P., Turnbull, D., Walker, K. A., Walkty, I., Wardle, D. A., Wehrle, V., Zander, R., and Zou, J.: Atmospheric Chemistry Experiment (ACE): mission overview, Geophys. Res. Lett., 32, L15S01, doi:10.1029/2005GL022386, 2005.

Bernath, P. F.: Atmospheric chemistry experiment (ACE): analytical chemistry from orbit, Trend. Anal. Chem., 25(7), 647-654, 2006.

Boone, C. D., Nassar, R., Walker, K. A., Rochon, Y., McLeod, S. D., Rinsland, C. P., and Bernath, P. F.: Retrievals for the atmospheric chemistry experiment Fourier-transform spectrometer, Appl. Optics, 44, 7218-7231, 2005.

Chance, K., Palmer, P., Spurr,V., Martin, R., Kurosu, T., and Jacob, D.: Satellite Observations of Formaldehyde Over North America from GOME, Geophys. Res. Lett., 27(21), 3461-3464, 2000.

Crawford, J., Davis, D., Olson, J., Chen, G., Liu, S., Gregory, G., Barrick, J., Sachse, G., Sandholm, S., Heikes, B., Singh, H., and Blake, D.: Assessment of upper tropospheric $\mathrm{HO}_{\mathrm{x}}$ sources over the tropical Pacific based on NASA GTE/PEM data: Net effect on $\mathrm{HO}_{\mathrm{x}}$ and other photochemical parameters, J. Geophys. Res., 104(D13), 16255, doi:10.1029/1999JD900106, 1999.

Coheur, P.-F., Herbin, H., Clerbaux, C., Hurtmans, D., Wespes, C., Carleer, M., Turquety, S., Rinsland, C. P., Remedios, J., Hauglustaine, D., Boone, C. D., and Bernath, P. F.: ACE-FTS observation of a young biomass burning plume: first reported measurements of $\mathrm{C} 2 \mathrm{H} 4, \mathrm{C}_{3} \mathrm{H}_{6} \mathrm{O}, \mathrm{H}_{2} \mathrm{CO}$ and $\mathrm{PAN}$ by infrared occultation from space, Atmos. Chem. Phys., 7, 5437-5446, 2007,

http://www.atmos-chem-phys.net/7/5437/2007/.

Dasgupta, P. K., Li, J., Zhang, G., Luke, W. T., Mcclenny, W. A., Stutz, J., and Fried, A.: Summertime ambient formaldehyde in five U.S. metropolitan areas: Nashville, Atlanta, Houston, Philadelphia, and Tampa, Environ. Sci. Technol., 39(13), 4767, doi:10.1021/es048327d, 2005.

De Serves, C.: Gas phase formaldehyde and peroxide measurements in the Artic atmosphere, J. Geophys. Res., 99, 25391, doi:10.1029/94JD00547, 1994.

Dufour, G., Boone, C. D., Rinsland, C. P., and Bernath, P. F.: First space-borne measurements of methanol inside aged southern tropical to mid-latitude biomass burning plumes using the ACE-FTS instrument, Atmos. Chem. Phys., 6, 3463-3470, 2006, http://www.atmos-chem-phys.net/6/3463/2006/.

Dufour, G., Szopa, S., Hauglustaine, D. A., Boone, C. D., Rinsland, C. P., and Bernath, P. F.: The Influence of Biogenic Emissions on Upper-Tropospheric Methanol as Revealed From Space, Atmos. Chem. Phys., 7, 6119-6129, 2007,

http://www.atmos-chem-phys.net/7/6119/2007/.

Dufour, G., Wittrock, F., Camredon, M., Beekmann, M., Richter, A., Aumont, B., and Burrows, J. P.: SCIAMACHY formaldehyde observations: constraint for isoprene emission estimates over Europe?, Atmos. Chem. Phys., 9, 1647-1664, 2009, http://www.atmos-chem-phys.net/9/1647/2009/.

Dunlea, E. J., DeCarlo, P. F., Aiken, A. C., Kimmel, J. R., Peltier, R. E., Weber, R. J., Tomlison, J., Collins, D. R., Shinozuka, Y., McNaughton, C. S., Howell, S. G., Clarke, A. D., Emmons, L. K., Apel, E. C., Pfister, G. G., van Donkelaar, A., Martin, R.
V., Millet, D. B., Heald, C. L., and Jimenez, J. L.: Evolution of Asian aerosols during transpacific transport in INTEX-B, Atmos. Chem. Phys. Discuss., 8, 15375-15461, 2008,

http://www.atmos-chem-phys-discuss.net/8/15375/2008/.

Fischer, H., Birk, M., Blom, C., Carli, B., Carlotti, M., von Clarmann, T., Delbouille, L., Dudhia, A., Ehhalt, D., Endemann, M., Flaud, J. M., Gessner, R., Kleinert, A., Koopman, R., Langen, J., López-Puertas, M., Mosner, P., Nett, H., Oelhaf, H., Perron, G., Remedios, J., Ridolfi, M., Stiller, G., and Zander, R.: MIPAS: an instrument for atmospheric and climate research, Atmos. Chem. Phys., 8, 2151-2188, 2008,

http://www.atmos-chem-phys.net/8/2151/2008/.

Folberth, G. A., Hauglustaine, D. A., Lathire, J., and Rocheton, F.: Interactive chemistry in the Laboratoire de Météorologie Dynamique general circulation model: model description and impact analysis of biogenic hydrocarbons on tropospheric chemistry, Atmos. Chem. Phys., 6, 2273-2319, 2006, http://www.atmos-chem-phys.net/6/2273/2006/.

Fried, A., Wert, B. P., Henry, B., and, Drummond, J. R.: Airborne tunable diode laser measurements of formaldehyde, Spectrochimica Acta Part A, 55, 2097, doi:10.1016/S13861425(99)00082-7, 1999.

Fried, A., Lee, Y.-N., Frost, G., Wert, B., Henry, B., Drummond, J. R., Hübler, G., and Jobson, T.: Airborne $\mathrm{CH}_{2} \mathrm{O}$ measurements over the North Atlantic during the 1997 NARE campaign: Instrument comparisons and distributions, J. Geophys. Res., 107(D4), 4039, doi:10.1029/2001JD000260, 2002.

Fried, A., Crawford, J., Olson, J., Walega, J., Potter, W., Wert, B., Jordan, C., Anderson, B., Shetter, R., Lefer, B., Blake, D., Blake, N., Meinardi, S., Heikes, B., O’Sullivan, D., Snow, J., Fuelberg, H., Kiley, C. M., Sandholm, S., Tan, D., Sachse, G., Singh, H., Faloona, I., Harward, C. N., and Carmichael, G. R.: Airborne tunable diode laser measurements of formaldehyde during TRACE-P: Distribution and box model comparisons, J. Geophys. Res., 108(D20), 8790, doi:10.1029/2003JD003451, 2003a.

Fried, A., Wang, Y., Cantrell, C., Wert, B., Walega, J., Ridley, B., Atlas, E., Shetter, R., Lefer, B., Coffey, M. T., Hannigan, J., Blake, D., Blake, N., Meinardi, S., Talbot, B., Dibb, J., Scheuer, E., Wingenter, O., Snow, J., Heikes, B., and Ehhalt, D.: Tunable diode laser measurements of formaldehyde during the TOPSE 2000 study: Distributions, trends, and model comparisons, J. Geophys. Res., 108(D4), 8365, doi:10.1029/2002JD002208, 2003b.

Fried, A., Walega, J., Olson, J. R., Crawford, J. H., Chen, G., Weibring, P., Richter, D., Roller, C., Tittel, F. K., Heikes, B., Snow, J., Shen, H., O'Sullivan, D., Porter, M, Fuelberg, H., Halland, J., and Millet, D. B.: Formaldehyde over North America and the North Atlantic during the summer 2004 INTEX campaign: Methods, observed distributions, and measurement-model comparisons, J. Geophys. Res., 113, D10302, doi:10.1029/2007JD009185, 2008a.

Fried, A., Olson, J. R., Walega, J. G., Crawford, J. H., Chen, G., Weibring, P., Richter, D., Roller, C., Tittel, F., Porter, M., Fuelberg, H., Halland, J., Bertram, T. H., Cohen, R. C., Pickering, K., Heikes, B. G., Snow, J. A., Shen, H., O’Sullivan, D. W., Brune, W. H., Ren, X., Blake, D. R., Blake, N., Sachse, G., Diskin, G. S., Podolske, J., Vay, S. A., Shetter, R. E., Hall, S. R., Anderson, B. E., Thornhill, L., Clarke, A. D., McNaughton, C. S., Singh, H. B., Avery, M. A., Huey, G., Kim, S., and Millet, D. B.: Role 
of convection in redistribution formaldehyde to the upper troposphere over North America and the North Atlantic during the summer 2004 INTEX campaign, J. Geophys. Res., 113, D17306, doi:10.1029/2007JD009760, 2008b.

Frost, G.J., Fried, A., Lee, Y.-N., Wert, B., Henry, B., Drummond, J. R., Evans, M. J., Fehsenfeld, F. C., Goldan, P. D., Holloway, J. S., Hübler, G., Jakoubek, R., Jobson, B. T., Knapp, K., Kuster, W. C., Roberts, J., Rudolph, J., Ryerson, T. B., Stohl, A., Stroud, C., Sueper, D. T., Trainer, M., and Williams, J.: Comparisons of box model calculations and measurements of formaldehyde from the 1997 North Atlantic Regional Experiment, J. Geophys., Res., 107(D8), 4060, doi:10.1029/2001JD000896, 2002.

Fu, D., Boone, C. D., Bernath, P. F., Walker, K. A., Nassar, R., Manney, G. L., and McLeod, S. D.: Global phosgene observations from the Atmospheric Chemistry Experiment (ACE) mission, Geophys. Res. Lett., 34, L17815, doi:10.1029/2007GL029942, 2007.

Giglio, L., van der Werf, G. R., Randerson, J. T., Collatz, G. J., and Kasibhatla, P.: Global estimation of burned areausing MODIS active fire observations, Atmos. Chem. Phys., 6, 957-974, 2006, http://www.atmos-chem-phys.net/6/957/2006/.

Gilpin, T., Apel, E., Fried, A., Wert, B., Calvert, J., Genfa, Z., Dasgupta, P., Harder, J. W., Heikes, B., Hopkins, B., Westberg, H., Kleindienst, T., Lee, Y.-N., Zhou, X., Lonneman, W., and Sewell, S.: Intercomparison of six ambient $\left[\mathrm{CH}_{2} \mathrm{O}\right]$ measurement techniques, J. Geophys. Res., 102(D17), 21161-21188, 1997.

Guenther, A., Karl, T., Harley, P., Wiedinmyer, C., Palmer, P. I., and Geron, C.: Estimates of global terrestrial isoprene emissions using MEGAN (Model of Emissions of Gases and Aerosols from Nature), Atmos. Chem. Phys., 6, 3181-3210, 2006, http://www.atmos-chem-phys.net/6/3181/2006/.

Hauglustaine, D. A., Hourdin, F., Jourdain, L., Filiberti, M.-A., Walters, S., Lamarque, J.-F., and Holland, E. A.: Interactive chemistry in the Laboratoire de Météorologie Dynamique general circulation model: Description and background tropospheric chemistry evaluation, J. Geophys. Res., 109, D04314, doi:10.1029/2003JD003957, 2004.

Heikes, B., Snow, J., Egli, P., O'Sullivan, D., Crawford, D., Olson, J., Chen, G., Davis, D., Blake, N., and Blake, D.: Formaldehyde over the central Pacific during PEM-Tropics B., J. Geosphys. Res., 106(D23), 32717, doi:10.1029/2001JD900012, 2001.

Horowitz, L. W., Liang, J., Gardner, G. M., and Jacob, D. J.: Export of reactive nitrogen from North America during summertime: Sensitivity to hydrocarbon chemistry, J. Geophys. Res., 103(D11), 13451-13476, doi:10.1029/97JD03142, 1998.

Jacob, D. J., Crawford, J. H. , Kleb, M. M., Connors, V. S., Bendura, R. J., Raper, J. L. Sachse, G. W., Gille, J. C., Emmons, L., and Heald, C. L.: Transport and Chemical Evolution over the Pacific (TRACE-P) aircraft mission: Design, execution, and first results, J. Geophys. Res., 108(D20), 9000, doi:10.1029/2002JD003276, 2003.

Jacobson, M. Z.: Computation of Global Photochemistry with SMVGEAR-II, Atmos. Environ., 29, 2541-2546, 1995.

Jacquinet-Husson, N., Scott, N. A., Chédin, A., Crépeau, L., Armante, R., Capelle, V., Orphal, J., Coustenis, A., Boone, C., Poulet-Crovisier, N., Barbe, A., Birk, M., Brown, L.R., CamyPeyret, C., Claveau, C., Chance, K., Christidis, N., Clerbaux, C., Coheur, P. F., Dana, V., Daumont, L., Debacker-Barilly, M. R., Di Lonardo, G., Flaud, J .M., Goldman, A., Hamdouni, A.,
Hess, M., Hurley, M. D., Jacquemart, D., Kleiner, I., Köpke, K., Mandin, J.Y., Massie, S., Mikhailenko, S., Nemtchinov, V., Nikitin, A., Newnham, D., Perrin, A., Perevalov, V. I., Pinnock, S., Régalia-Jarlot, L., Rinsland, C. P., Rublev, A., Schreier, F., Schult, L., Smith, K. M., Tashkun, S. A., Teffo, J. L., Toth, R. A., Tyuterev, V. 1. G., Vander Auwera, J., Varanasi, P., Wagner, G.: The GEISA spectroscopic database: Current and future archive for Earth and planetary atmosphere studies, J. Quant. Spectrosc. Ra., 109, 1043, 2008.

Kesselmeier, J. and Staudt, M.: Biogenic volatile organic compounds (VOC): an overview on emission, Physiology and Ecology, J. Atmos. Chem., 33, 23-88, 1999.

Kesselmeier, J., Kuhn, U., Rottenberger, S., Biesenthal, T., Wolf, A., Schebeske, G., Andreae, M. O., Ciccioli, P., Brancaleoni, E., Frattoni, M., Oliva,V, Botelho, M. L., Silva, C. M. A., and Tavares, T. M.: Concentrations and species composition of atmospheric volatile organic compounds (VOCs) as observed during the wet and dry season in Rondônia (Amazonia), J. Geophys. Res., 107(D20), 8053, doi:10.1029/2000JD000267, 2002.

Kormann, R., Fischer, H., de Reus, M., Lawrence, M., Brhl, Ch., von Kuhlmann, R., Holzinger, R., Williams, J., Lelieveld, J., Warneke, C., de Gouw, J., Heland, J., Ziereis, H., and Schlager, H.: Formaldehyde over the eastern Mediterranean during MINOS: Comparison of airborne in-situ measurements with 3-Dmodel results, Atmos. Chem. Phys., 3, 851-861, 2003, http://www.atmos-chem-phys.net/3/851/2003/.

Lathière, J., Hauglustaine, D. A., De Noblet-Ducoudré, N., Krinner, G., and Folberth, G. A.: Past and future changes in biogenic volatile organic compound emissions simulated with a global dynamic vegetation model, Geophys. Res. Lett., 32(20), L20818, doi:10.1029/2005GL024164, 2005.

Lathière, J., Hauglustaine, D. A., Friend, A. D., De NobletDucoudré, N., Viovy, N., and Folberth, G. A.: Impact of climate variability and land use changes on global biogenic volatile organic compound emissions, Atmos. Chem. Phys., 6, 2129-2146, 2006, http://www.atmos-chem-phys.net/6/2129/2006/.

Lee, M., Heikes, B. G., Jacob, D. J., Sachse, G., and Anderson, B.: Hydrogen peroxide, organic hydroperoxide, and formaldehyde as primary pollutants from biomass burning, J. Geophys. Res., 102(D1), 1301, doi:10.1029/96JD01709, 1997.

Liu, H. Y., Jacob, D. J., Bey, I., and Yantosca, R. M.: Constraints from $\mathrm{Pb}-210$ and $\mathrm{Be}-7$ on wet deposition and transport in a global three-dimensional chemical tracer model driven by assimilated meteorological fields, J. Geophys. Res., 106, 12109 12128, 2001.

Mari, C., Jacob, D. J., and Bechtold, P.: Transport and scavenging of soluble gases in a deep convective cloud, J. Geophys. Res., 105, 22255-22267, 2000.

Millet, D. B., Jacob, D. J., Boersma, K. F., Fu, T., Kurosu, T. P., Chance, K., Heald, C. L., and Guenther, A.: Spatial distribution of isoprene emissions from North America derived from formaldehyde column measurements by the OMI satellite sensor, J. Geophys. Res., 113, D02307, doi:10.1029/2007JD008950, 2008.

Oliver, J. G. J. and Berdowski, J. J. M.: Global emissions sources and sinks, in: The Climate System, edited by: Berdowski, J., Guicherit, R., and Heij, B. J., A. Balkema Publishers/Swets \& Zeitlinger Publishers, Lisse, The Netherlands, 33-78 pp., 2001.

Palmer; P. I., Jacob, D. J., Chance, K., Martin, R. V., Spurr, 
R. J. D., Kurosu, T. P., Bey, I., Yantosca, R., Fiore, A., and Li, Q.: Air mass factor formulation for spectroscopic measurements from satellites: Application to formaldehyde retrievals from the Global Ozone Monitoring Experiment, J. Geophys. Res., 106(D13), 14539-14550, 2001.

Palmer, P. I., Jacob, D. J., Fiore, A. M., Martin, R. V., Chance, K., and Kurosu, T. P.: Mapping isoprene emissions over North America using formaldehyde column observations from space, J. Geophys. Res., 108(D6), 4180, doi:10.1029/2002JD002153, 2003.

Palmer, P. I., Abbot, D. S., Fu, T.-M., Jacob, D. J., Chance, K., Kurosu, T. P., Guenther, A., Wiedinmyer, C., Stanton, J. C., Pilling, M. J., Pressley, S. N., Lamb, B., and Sumner, A. L.: Quantifying the seasonal and interannual variability of North American isoprene emissions using satellite observations of formaldehyde column, J. Geophys. Res., D12315, doi:10.1029/2005JD006689, 2006.

Pfister, G. G., Emmons, L. K., Hess, P. G., Lamarque, J.-F., Orlando, J. J., Walters, S., Guenther, A., Palmer, P. I., and Lawrence, P. J.: Contribution of isoprene to chemical budgets: A model tracer study with the NCAR CTM MOZART-4, J. Geophys. Res., 113, D05308, doi:10.1029/2007JD008948, 2008.

Perrin, A., Keller, F., and Flaud, J.-M.: New analysis of the $v_{2}$, $v_{3}, v_{4}$ and $v_{6}$ bands of formaldehyde $\mathrm{H}_{2}^{12} \mathrm{C}^{16} \mathrm{O}$, Line positions and intensities in the 5-10 $\mu \mathrm{m}$ spectral region, J. Mol. Spectrosc., 221, 192-198, 2003.

Perrin, A., Valentin, A., Daumont, L.: New analysis of the $2 v_{4}$, $v_{4}+v_{6}, 2 v_{6}, v_{3}+v_{4}, v_{3}+v_{6}, v_{1}, v_{5}, v_{2}+v_{4}, 2 v_{3}, v_{2}+v_{6}$ and $v_{2}+v_{3}$ bands of formaldehyde $\mathrm{H}_{2}^{12} \mathrm{C}^{16} \mathrm{O}$ : Line positions and intensities in the $3.5 \mu \mathrm{m}$ spectral region, J. Mol. Struct., 780781, 28-44, 2006.

Perrin, A., Jacquemart, D., Kwabia Tchana, F., and Lacome, N.: Absolute line intensities and new linelists for the 5.7 and $3.6 \mu \mathrm{m}$ bands of formaldehyde, J. Quant. Spectrosc. Ra. , 110, 700-716, 2009.

Ricaud, P., Alexandre, D., Barret, B., Flochmoën, E. L., Motte, E., Berthet, G., Lefèvre, F., and Murtagh, D.: Measurements of midstratospheric formaldehyde from the Odin/SMR instrument, J. Quant. Spectrosc. Ra., 107, 91-104, 2007.

Rinsland, C. P., Dufour, G., Boone, C. D., Bernath, P. F., and Chiou, L.: Atmospheric Chemistry Experiment (ACE) measurements of elevated Southern Hemisphere upper tropospheric $\mathrm{CO}, \mathrm{C}_{2} \mathrm{H}_{6}$, $\mathrm{HCN}$, and $\mathrm{C}_{2} \mathrm{H}_{2}$ mixing ratios from biomass burning emissions and long-range transport, Geophys. Res. Lett., 32(20), L20803, doi:10.1029/2005GL024214, 2005.

Rothman, L. S., Jacquemart, D., Barbe, A., Benner, D. C., Birk, M., Brown, L. R., Carleer, M. R., Chackerian Jr., C., Chance, K., Coudert, L. H., Dana, D., Devi, V.M., Flaud, J.-M., Gamache, R.R., Goldman, A., Hartmann, J.-M., Jucks, K. W., Maki, A. G., Mandin, J.-M., Massie, S. T., Orphal, J., Perrin, A., Rinsland, C.P., Smith, M.A.H., Tennyson, J., Tolchenov, R.N., Toth, R.A., Vander Auwera, J., Varanasi, P., and Wagner, G.: The HITRAN 2004 molecular spectroscopic database, J. Quant. Spectrosc. Ra., 96, 139-204, 2005.

Singh, H., Chen, Y., Tabazadeh, A., Fukui, Y., Bey, I., Yantosca, R., Jacob, D., Arnold, F., Wohlfrom, K., Atlas, E., Flocke, F., Blake, D., Blake, N., Heikes, B., Snow, J., Talbot, R., Gregory, G., Sachse, G., Vay, S., and Kondo, Y.: Distribution and fate of selected oxygenated organic species in the troposphere and lower stratosphere over the Atlantic, J. Geophys. Res., 105(D3), 3795, doi:10.1029/1999JD900779, 2000.

Singh, H. B., Salas, L. J., Chatfield, R. B., Czech, E., Fried, A., Walega, J., Evans, M. J., Field, B. D., Jacob, D. J., Blake, D., Heikes, B., Talbot, R., Sachse, G., Crawford, J. H., Avery, M. A., Sandholm, S., and Fuelberg, H.: Analysis of the atmospheric distribution, sources, and sinks of oxygenated volatile organic chemicals based on measurements over the Pacific during TRACE-P, J. Geophys. Res., 109, D15S07, doi:10.1029/2003JD003883, 2004.

Singh, H. B., Brune, W. H., Crawford, J. H., Jacob, D. J., and Russell, P. B.: Overview of the summer 2004 Intercontinental Chemical Transport Experiment-North America (INTEX-A), J. Geophys. Res., 111, D24S01, doi:10.1029/2006JD007905, 2006.

Stavrakou, T., Müller, J.-F., De Smedt, I., Van Roozendael, M., van der Werf, G. R., Giglio, L., and Guenther, A.: Evaluating the performance of pyrogenic and biogenic emission inventories against one decade of space-based formaldehyde columns, Atmos. Chem. Phys., 9, 1037-1060, 2009,

http://www.atmos-chem-phys.net/9/1037/2009/.

Steck, T., Glatthor, N., von Clarmann, T., Fischer, H., Flaud, J. M., Funke, B., Grabowski, U., Höpfner, M., Kellmann, S., Linden, A., Perrin, A., and Stiller, G. P.: Retrieval of global upper tropospheric and stratospheric formaldehyde $\left(\mathrm{H}_{2} \mathrm{CO}\right)$ distributions from high-resolution MIPAS-Envisat spectra, Atmos. Chem. Phys., 8, 463-470, 2008,

http://www.atmos-chem-phys.net/8/463/2008/.

Stickler, A., Fischer, H., Williams, J., de Reus, M., Sander, R., Lawrence, M. G., Crowley, J. N., and Lelieveld, J.: Influence of summertime deep convection on formaldehyde in the middle and upper troposphere over Europe, J. Geophys. Res., 111, D14308, doi:10.1029/2005JD007001, 2006.

van der Werf, G. R., Randerson, J. T., Collatz, G. J., Giglio, L., Kasibhatla, P. S., Arellano, A. F., Olsen, S. C., and Kasischke, E. S.: Continental-scale partitioning of fire emissions during the 1997 to 2001 El Nino/La Nina period, Science, 303(5654), 73$76,2004$.

van der Werf, G. R., Randerson, J. T., Giglio, L., Collatz, G. J., Kasibhatla, P. S., and Arellano Jr., A. F.: Interannual variability in global biomass burning emissions from 1997 to 2004, Atmos. Chem. Phys., 6, 3423-3441, 2006, http://www.atmos-chem-phys.net/6/3423/2006/.

Wang, Y. H., Jacob, D. J., and Logan, J. A.: Global simulation of tropospheric $\mathrm{O}_{3}-\mathrm{NO}_{\mathrm{X}}$-hydrocarbon chemistry: 1. Model formulation, J. Geophys. Res., 103, 10713-10 725, 1998.

Wert, B. P., Fried, A., Rauenbuehler, S., Walega, J., and Henry, B.: Design and performance of a tunable diode laser absorption spectrometer for airborne formaldehyde measurements, J. Geophys. Res., 108(D12), 4350, doi:10.1029/2002JD002872, 2003.

Wesely, M. L.: Parameterization of surface resistances to gaseous dry deposition in regional scale numerical models, Atmos. Environ., 23, 1293-1304, 1989.

Wittrock, F., Richter, A., Oetjen, H., Burrows, J. P., Kanakidou, M., Myriokefalitakis, S., Volkmer, R., Beirle, S., Platt, U., and Wagner, T.: Simultaneous global observations of glyoxal and formaldehyde from space, Geophys. Res. Lett., 33, L16804, doi:10.1029/2006GL026310, 2006. 